\title{
WPŁYW COVID-19 NA NASTAWIENIE I CREDIT RATINGI KRAJÓW
}

\section{Abstract \\ COVID-19 IMPACT ON COUNTIRES' OUTLOOKS AND CREDIT RATINGS}

The aim of the study is to examine the impact of the financial crisis caused by COVID-19 on changes in outlooks and credit ratings of major rating agencies. The research hypothesis was as follows: the financial crisis caused by COVID-19 negatively affected the change in outlooks and credit ratings of countries. The study used long-term and short-term credit ratings and outlooks collected from the Thomson Reuters / Refinitiv database regarding liabilities expressed in foreign currency and macroeconomic data from the International Monetary Fund databases, for 2010-2021. The analysis was carried out using ordered logit panel models. The presented results showed a weak significant impact of the COVID-19 pandemic on credit rating. The agency that changed its notes in connection with this situation is Standard \& Poor's (S\&P). However, the attitude responded to the situation under investigation. During the crisis, country ratings have become less sensitive to growing debt, which may be dictated by widespread loosening of fiscal policy. The rate of GDP growth has a particular impact during the COVID-19 period in the event of a change of outlook. Rising inflation is particularly dangerous in the age of pandemics. It may be related to monetary policy easing.

Keywords: COVID-19, credit rating, outlook

\section{Wprowadzenie}

Rok 2020 okazał się rokiem niepokoju związanym z pojawieniem się epidemii COVID-19. Tajemnicza choroba - spokrewniona z SARS, ale posiadająca również cechy innych groźnych chorób - została oficjalnie odnotowana 1 grudnia 2019 roku w Wuhan. Ze względu na ciężkie powikłania, które powoduje, brak szczepionki i konkretnych leków zwalczających jej objawy, a także silne obciążenie służby zdrowia - bez względu na poziom rozwoju gospodarczego kraju - zmusiła rządy do częściowej lub całkowitej narodowej kwarantanny (ang. lockdown). Na rysunku 1 
przedstawiono główne wydarzenia związane z rynkiem finansowym oraz zamykaniem gospodarek w wyniku COVID-19.

\section{Rysunek 1. Najważniejsze wydarzenia związane z COVID-19}

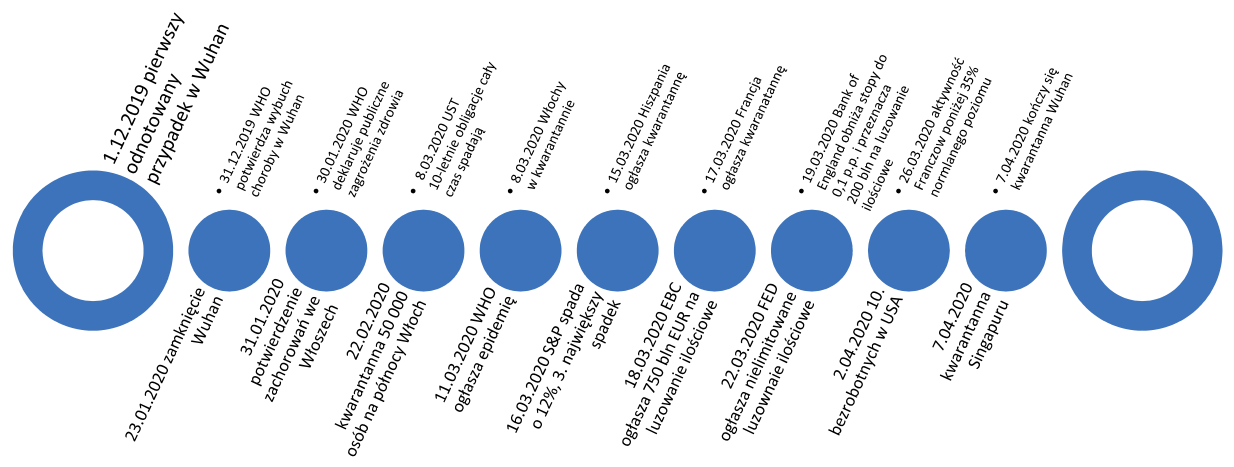

Źródło: opracowanie własne.

Zamrażanie gospodarek krajów jest w znacznej mierze wynikiem zachorowalności, obciążenia służby zdrowia i śmiertelności w wyniku zarażenia. Ponieważ około 80\% zakażonych COVID-19 nie ma objawów, izolacja stała się podstawowym środkiem zwalczania epidemii. Krajami, które najbardziej ucierpiały w wyniku COVID-19, okazały się między innymi Stany Zjednoczone, Hiszpania, Włochy, Francja, Wielka Brytania, Niemcy, Turcja, Rosja, Iran, Chiny, Brazylia, Kanada, Belgia, Holandia. 29 kwietnia 2020 roku odnotowano ponad 3,2 miliona przypadków choroby i około 218 tysięcy ofiar śmiertelnych (5,8 miliona wykonanych testów) (https://gisanddata.maps.arcgis.com/apps/opsdashboard/index.html\#/bda75947 40fd40299423467b48e9ecf6).

W związku z rosnącą liczbą przypadków zakażeń większość krajów wprowadziła kwarantannę narodową. Wyjątkiem od tej reguły była na przykład Szwecja. W tabeli 1 przedstawiono kraje pod względem udziału w globalnym PKB z uwzględnieniem rodzaju kwarantanny.

Tabela 1. Kwarantanna narodowa w wybranych krajach a udział w światowym PKB w 2019 roku

\begin{tabular}{|l|l|l|l|l|l|}
\hline \multicolumn{1}{|c|}{ Kraj } & Kwarantanna & $\begin{array}{c}\text { \% globalnego } \\
\text { PKB }\end{array}$ & \multicolumn{1}{|c|}{ Kraj } & Kwarantanna & $\begin{array}{c}\text { \% globalnego } \\
\text { PKB }\end{array}$ \\
\hline $\begin{array}{l}\text { Stany } \\
\text { Zjednoczone }\end{array}$ & częściowa & 24,6 & Rosja & częściowa & 1,9 \\
\hline Chiny & częściowa & 16,4 & Korea & częściowa & 1,9 \\
\hline Japonia & ograniczona & 5,8 & Hiszpania & pełna & 1,6 \\
\hline
\end{tabular}




\begin{tabular}{|l|l|l|l|l|l|}
\hline Niemcy & pełna & 4,4 & Australia & pełna & 1,6 \\
\hline Indie & pełna & 3,7 & Meksyk & częściowa & 1,4 \\
\hline Wielka Brytania & pełna & 3,2 & Indonezja & pełna & 1,3 \\
\hline Francja & pełna & 3,1 & Holandia & częściowa & 1 \\
\hline Włochy & pełna & 2,3 & $\begin{array}{l}\text { Arabia } \\
\text { Saudyjska }\end{array}$ & częściowa & 0,9 \\
\hline Brazylia & częściowa & 2,1 & Turcja & częściowa & 0,9 \\
\hline
\end{tabular}

Źródło: opracowanie własne.

Przedstawiane informacje (za Peterem Druckerem rozumiane jako zasób) na temat kondycji finansowej gospodarek oraz liczby przypadków chorych na COVID-19 przyczyniają się do oceny ryzyka upadłości krajów. Zarządzanie informacją - w ujęciu Bogusława Nierenberga (2011, s. 97-98) - wpływa na kreowanie wizerunku kraju jako radzącego sobie lub nie z pandemią. Jednocześnie podawanie informacji na temat aktualnych i prognozowanych danych ekonomicznych, w tym programów pomocowych, może oddziaływać na sytuację ekonomiczną kraju.

Przedstawione dane oraz brak badań w zakresie wpływu COVID-19 na kondycję finansową gospodarek mierzoną credit ratingami skłoniła do postawienia celu pracy, jakim jest zbadanie wpływu kryzysu finansowego wywołanego przez COVID-19 na zmiany nastawienia oraz credit ratingów prezentowanych przez największe agencje ratingowe. Postawiony cel jest wynikiem postrzegania prezentowanego kryzysu przez agencje ratingowe. W zaistniałej sytuacji postawiono hipotezę badawczą brzmiącą następująco: kryzys finansowy wywołany COVID-19 wpłynął negatywnie na zmiany nastawienia i credit ratingów krajów.

Aby zrealizować postawiony cel, postanowiono porównać dotychczasowe kryzysy finansowe z kryzysem wywołanym przez COVID-19. Odniesiono się również do dotychczasowych zmian ratingów w przypadku kryzysu finansowego. Następnie dokonano analizy prognoz wybranych krajów. W ostatnim etapie dokonano empirycznego badania zmian credit ratingów krajów w czasie wspomnianego kryzysu.

\section{Przegląd literatury}

Istnieje wiele definicji związanych z kryzysem finansowym. Kryzys można określić jako załamanie koniunktury prowadzące do znacznego spadku produkcji i tym samym do zmniejszenia tempa wzrostu gospodarczego (Chrabonszczewska, 2005, s. 315) lub jako nagłe załamanie powstałe na rynku finansowym związane z brakiem płynności i niewypłacalności podmiotów rynkowych, zmuszające do interwencji (Miklaszewski, 2003, s. 99). Według Franklina Allena i innych (2009) można wyróżnić: kryzys bankowy, kryzys płynności, efekt zakażania i bąble spekulacyjne 
na rynku aktywów finansowych. Kryzys może odnosić się do danego sektora, obszaru lub sposobu pojawiania się (Borcuch, 2009).

Klasyczny kryzys na rynku finansowym odnosi się do gwałtownych zmian wiążących się z niedoborem płynności lub niewypłacalnością uczestników rynku oraz interwencjami publicznymi (Bordo et al., 2000, s. 55). Wśród jego przyczyn Hyman Minsky (1986) upatruje:

- zmianę struktury finansowania,

- zmianę struktury zobowiązań,

- refinansowanie długu,

- dynamiczny rozwój nowoczesnych instrumentów finansowania,

- deregulację rynku finansowego,

- wzrost skłonności do ryzyka.

Graciela L. Kaminsky (2003) za pomocą metody drzewa regresyjnego poddała badaniu 96 przypadków zdarzeń kryzysowych dla 20 krajów (rozwiniętych, wschodzących i rozwijających się) w latach 1970-2001. Wyodrębniła sześć kategorii identyfikujących główną przyczynę pojawienia się kryzysu:

- pogorszenie się sytuacji na rachunku obrotów bieżących;

- wstrząsy na rynkach finansowych;

- problemy z zadłużeniem zagranicznym;

- nierównowaga fiskalna;

- nagłe odcięcie napływów kapitałowych wywołane wzrostem stóp procentowych na świecie;

- samospełniające się kryzysy, które trudno wiązać z wyraźnym pogorszeniem zmiennych fundamentalnych.

Przedstawione rozważania pomagają rozpoznać zjawiska kryzysowe w ostatnim okresie. Zmiany, jakie nastąpiły, nie były typową przyczyną kryzysu na rynku finansowym. Pandemia i spowodowane nią decyzje krajów doprowadziły do zmniejszenia konsumpcji w obawie przed utratą pracy, co wywołało spadek produkcji i rosnące bezrobocie. Przed ogłoszeniem pandemii nie obserwowano tego typu przesłanek.

Powstaje zatem pytanie o zachowanie agencji ratingowych w czasie kryzysu, a tym samym zmiany nastawienia i ratingów z tytułu kryzysu wywołanego pandemią. Aby odnieść się do wskazanej tematyki, należy zwrócić uwagę na dotychczasowe reakcje agencji ratingowych w czasie kryzysu. Badania można podzielić na dwie grupy. Pierwsza z nich zakłada, że credit ratingi mają charakter procykliczny. Edward Altman i Herbert A. Rijken (2009) dowiedli, że agencje ratingowe szybciej dokonują obniżki not, niż poprawiają ratingi. Heski Bar-Isaac i Joel Shapiro (2013) wykazali, że jakość ratingów spada w czasie boomu gospodarczego. Agencje ratingowe podczas oceny biorą pod uwagę dane z kilku lat, co powoduje ograniczenie wpływu wahań krótkoterminowych, jednak obserwuje się zależności między cyklem koniunkturalnym a credit ratingami (Amato, Furfine, 2004; Feng et al., 2008; Kim, Sohn, 2008). Jeffery D. Amato i Craig H. Furfine (2004) wskazują, że spadek 
ratingów może wynikać z makroekonomicznych efektów cyklu koniunkturalnego. Niemniej jednak twierdzą, że nie znaleźli żadnych dowodów na to, że ratingi są nadmiernie uzależnione od cyklu koniunkturalnego, a zatem agencje osiągają formę stabilności ratingowej. Ratingi inwestycyjne są bardziej cykliczne, ponieważ wskaźniki ekonomiczne mają znaczny wpływ na ocenę. Prezentowaną zależność potwierdził Hollis Ashbaugh-Skaife (et al., 2006). Analizując wyłącznie nowe zmiany oceny, wykazał, że procykliczność jest silniejsza. Standardy nadawania ratingów stały się łagodniejsze. Badania Marshalla Blume’a (et al., 1998) sugerowały odwrotne zjawisko. Amato i Furfine (2004) podważają jednak te wyniki, sugerując, że są one ograniczone do ocen globalnych, istnieją natomiast liczne przypadki niezmienionych ocen. Feng i inni (2008), wykorzystując model probitowy do ukazania wpływu cyklu koniunkturalnego na ratingi korporacyjne, twierdzą, że agencje ratingowe zmieniają noty ad hoc. Amato i Furfine (2004) sugerują, że indywidualne czynniki ryzyka biznesowego korporacji mogą wykazywać cykliczne zachowania, a tym samym cykliczne zachowanie ratingów korporacyjnych. Ed deHaan (2017) nie zauważa spadku wydajności korporacyjnych credit ratingów podczas kryzysu ani po nim, co wskazuje, że niepowodzenia ratingów instrumentów finansowych były spowodowane warunkami wyjątkowymi dla rodzajów instrumentów finansowych. Większa część testów wskazuje raczej, że wyniki ratingu korporacyjnego poprawiają się po kryzysie, co jest zgodne z reakcją agencji na krytykę publiczną i presję regulacyjną. Jednocześnie prezentuje dowody na to, że wyrafinowani uczestnicy rynku zmniejszają swoje zaufanie do korporacyjnych ratingów kredytowych po kryzysie. Zgodnie z teoretycznymi modelami cykliczności reputacji prawdopodobnym wyjaśnieniem jest to, że agencje ratingowe ponoszą szkodę w wyniku utraty reputacji na skutek nieudanych ocen instrumentów finansowych. Giulia Mennillo i Timothy J. Sinclair (2019) sugerują, że taka sytuacja jest spowodowana brakiem rozumienia celowości credit ratingów.

Gunter Löffler (2004) dowiódł stabilności ratingów nawet w czasie kryzysu finansowego. Próba unikania przez agencje częstych zmian ratingów może prowadzić do empirycznie obserwowanej stabilności ratingów, seryjnej zależności zmian ratingów oraz opóźnienia zmian ratingów względem zmian ryzyka niewypłacalności emitenta (Guttler, Raupach, 2010). Praktyczne konsekwencje perspektywy cyklu koniunkturalnego zostały podkreślone przez Altmana i Rijkena (2009). Zauważają oni, że agencje ratingowe tylko częściowo dostosowują oceny do faktycznej jakości kredytowej. Rzadko ma miejsce obniżka ratingów. Częściej obserwuje się brak jej zmian.

W pierwszych badaniach dotyczących wpływu cyku koniunkturalnego na ratingi krajów wykorzystano zmiany PKB (Cantor, Packer, 1996). Następnie wprowadzono pojęcie dekompozycji nieliniowej obrazującej istotność cyklu koniunkturalnego podczas oceny credit ratingów (Ferri et al., 1999). Polega ona na uwzględnieniu w dekompozycji spreadów na CDS-ach. Badania dotyczące wpływu cyklu koniunkturalnego na credit ratingi krajów prowadzone były również przez Paola Giacomino (2013) i Lennarta Freitaga (2015). Większość prac odnosiła się do dużych 
agencji ratingowych, co podyktowane było brakiem analiz credit ratingów krajów publikowanych przez mniejsze podmioty. I tak, analizując credit ratingi Standard \& Poor's (dalej: S\&P), Amato i Furfine (2004) dowiedli istotnego wpływu kryzysu na credit ratingi i nastawienie. Roman Kräussl (2003), badając przyczynowość między wpływem cyklu koniunkturalnego a credit ratingami, nie zaobserwował istotnego związku.

Roberto A. De Santis (2012), analizując wpływ credit ratingów krajów na ratingi innych podmiotów, wykazał, że nie tylko same ratingi reagują na zmiany cyklu koniunkturalnego, ale także ich zmiana przyczynia się do efektu spirali. Do podobnych wniosków doszła Patrycja Chodnicka-Jaworska (2019). Jun Kyung Auh (2013) z kolei podzielił okres obserwacji na trzy fazy, a mianowicie: przed, $w$ trakcie i po zakończeniu kryzysu. Dowiódł, że credit ratingi ulegają pogorszeniu w czasie kryzysu, w szczególności dotyczy to podmiotów rolujących swój dług. Löffler (2004) podkreśla jednak, że ratingi podlegają zmianom w czasie kryzysu, lecz sama korekta przebiega z opóźnieniem.

Wyniki wpływu cyklu koniunkturalnego na credit ratingi nie są jednoznaczne. Istnieje grupa badań wskazująca na brak takiej zależności lub antycykliczność not. Jedną z najpopularniejszych prac na ten temat jest badanie Bar-Isaaca oraz Shapiro (2013). Antycykliczność podyktowana jest opóźnieniem reakcji agencji ratingowych na zmiany uwarunkowań. Według badaczy ma to związek z rodzajem finansowania credit ratingów. Noty opłacane są przez emitenta długu, nie przez inwestora. W związku z tym znaczna i szybka obniżka ratingów mogłaby skłonić ocenianego do wycofania się z procesu oceny. Jakość i tym samym szybkość reakcji ratingów spada wraz ze wzrostem opłat za ich nadawanie. Ponadto wpływ na tę sytuację ma prawdopodobieństwo upadłości podmiotu lub kraju. Zawyżone oceny - zgodnie z prezentowanymi badaniami - obserwowane są w momencie ożywienia gospodarczego, ze względu na małe prawdopodobieństwo upadłości i tym samym niskie ryzyko utraty reputacji agencji ratingowej wynikające z nadania zawyżonej noty (Chodnicka-Jaworska, 2017). Zjawisko to ma miejsce w szczególności w przypadku występowania na rynku naiwnych inwestorów. Freitag (2015) dowodzi niskiej zmienności not. Odnotowuje ponadto częstszą skłonność do obniżek niż poprawy ocen.

Część badaczy zwraca uwagę na zasadność obniżek ratingów w dobie kryzysu. I tak Julien Trouillet (2015) wykazuje co prawda obniżkę ratingów w czasie dekoniunktury i poprawę not w okresie koniunktury, zaznacza jednak, że obniżka not w dobie kryzysu przyczynia się do pogorszenia sytuacji i tym samym pogłębienia kryzysu.

Same metodologie oceny w czasie kryzysu podlegają zmianom (Isakin, David, 2015). Starsze transze wyemitowanych papierów dłużnych oceniane są wyżej niż nowsze emisje.

Prezentowane różnice w wynikach badań skłoniły do analizy zmian credit ratingów i nastawienia w początkowych momentach kryzysu wywołanego COVID-19. 
Aby móc odnieść się do oceny, analizę poprzedzono przeglądem kondycji wybranych gospodarek i prognoz dotyczących ich zmiany.

\section{Opis danych i metodologia}

\subsection{Kondycja finansowa gospodarek}

Perspektywy dla globalnej gospodarki gwałtownie się pogorszyły, ponieważ liczba przypadków COVID-19 nadal rośnie. Dostrzega się ryzyko pogorszenia prognoz w zależności od tego, jak ostry i długotrwały będzie kryzys. Spadek globalnego wzrostu może ostatecznie przekroczyć 3,0\%. Oczekuje się gwałtownego spadku globalnej aktywności gospodarczej w drugim kwartale, gdyż większość światowej gospodarki pozostaje w pewien sposób zablokowana, ale nadal oczekuje się ożywienia w czwartym kwartale 2020 roku. Gdy powstrzymanie rozprzestrzeniania się nowych przypadków zajmie więcej czasu lub pojawi się ryzyko drugiej fali epidemii, oznacza to słabszy wzrost w 2020 roku - ożywienie nastąpiłoby dopiero w 2021.

Należy zauważyć znaczną rozbieżność między wynikami rynków finansowych a gospodarką realną. Gwałtowny wzrost na rynkach finansowych od końca marca sugeruje, że uczestnicy rynku z zadowoleniem przyjęli wiadomości o możliwości „spłaszczenia krzywej” i rynek wydaje się wyceniać ożywienie w kształcie litery V dla globalnej gospodarki, co sugeruje, że blokady zostaną zniesione szybciej niż zakładano. Co więcej, decyzja Rezerwy Federalnej Stanów Zjednoczonych (FED) dotycząca bezpośredniego wsparcia obligacji korporacyjnych, a szczególnie długu o wysokiej rentowności, miała znaczący wpływ na zapobieżenie wykluczenia firm z rynków finansowania. Ponadto rentowności gwałtownie spadły. Jeśli Rezerwa Federalna będzie w stanie zakotwiczyć rentowności, może to ograniczyć liczbę bankructw, pozostawiając sektor przedsiębiorstw w silniejszej pozycji po zniesieniu blokad. W tej chwili jest jeszcze za wcześnie, aby wiedzieć, czy rynki finansowe dokładnie wyceniają szybsze ożywienie lub czy pogorszenie koniunktury po raz kolejny obniży ceny na rynkach akcji i obligacji.

Rynki rozwinięte i wschodzące przeżyją ostre uderzenie w nadchodzących miesiącach. Obserwuje się potencjalne ryzyko dłuższego efektu w przypadku rynków rozwijających się, co może spowolnić odbicie z trzech powodów. Po pierwsze, wiele krajów będzie starało się testować, diagnozować i powstrzymywać wirusa - wymaga to jednak znacznej siły instytucjonalnej i dostępu do opieki zdrowotnej. Po drugie, pomimo sporego poluzowania polityki monetarnej rentowności obligacji na rynkach wschodzących wzrosły, zwłaszcza w krajach o słabszych filarach. Po trzecie, biorąc pod uwagę presję na finansowanie i ogólne ograniczenia makroekonomiczne, rządy tej grupy krajów również będą w mniejszym stopniu w stanie wprowadzić znaczący bodziec fiskalny podobny do tego obserwowanego w krajach rozwiniętych. 
Tabela 2. Zmiany stóp procentowych wprowadzone przez banki centralne

\begin{tabular}{|l|l|l|l|}
\hline \multicolumn{1}{|c|}{ Kraj } & \multicolumn{1}{c|}{ Stopa procentowa } & \multicolumn{1}{c|}{ Data zmiany } & \multicolumn{1}{c|}{ Poprzednia stopa } \\
\hline Argentyna & 38 & 27.04 .2020 & 39 \\
\hline Australia & 0,25 & 19.03 .2020 & 0,5 \\
\hline Brazylia & 3,75 & 18.03 .2020 & 4,25 \\
\hline Kanada & 0,25 & 27.03 .2020 & 0,75 \\
\hline Chiny & 3,85 & 20.04 .2020 & 4,5 \\
\hline Strefa euro & 0 & 10.03 .2016 & 0,05 \\
\hline Francja & 0 & 10.03 .2016 & 0,05 \\
\hline Niemcy & 0 & 10.03 .2016 & 0,05 \\
\hline Indie & 3,4 & 27.03 .2020 & 5,25 \\
\hline Indonezja & 3,5 & 14.04 .2020 & 4,5 \\
\hline Włochy & 0 & 10.03 .2016 & 0,05 \\
\hline Japonia & $-0,1$ & 16.02 .2016 & - \\
\hline Meksyk & 6 & 27.04 .2020 & 6 \\
\hline Nowa Zelandia & 0 & 28.04 .2020 & 25 \\
\hline Rosja & 5,5 & 27.04 .2020 & 6 \\
\hline Arabia Saudyjkka & 0,5 & 17.03 .2020 & 1,25 \\
\hline Singapur & 0,12 & 28.04 .2020 & 0,14 \\
\hline $\begin{array}{l}\text { Republika Południowej } \\
\text { Afryki }\end{array}$ & 4,25 & 14.04 .2020 & 5,25 \\
\hline Korea & 0,75 & 16.03 .2020 & 1,25 \\
\hline Hiszpania & 0 & 10.03 .2016 & 0,05 \\
\hline Szwajcaria & $-0,75$ & 19.03 .2020 & $-0,75$ \\
\hline Turcja & 8,75 & 22.04 .2020 & 9,75 \\
\hline Wielka Brytania & 0 & 19.03 .2020 & 0,25 \\
\hline Stany Zjednoczone & 0,25 & 15.03 .2020 & 1,25 \\
\hline Zodin & & & \\
\hline
\end{tabular}

Źródło: opracowanie własne na podstawie bazy Thomson Reuters.

Blokady i dystans społeczny będą miały poważne konsekwencje dla gospodarek rozwiniętych. Oczekuje się spadku o 3,0\% w 2020 roku. Wsparcie podatkowe i polityka pieniężna nie będą wystarczające, aby zrównoważyć hamowanie gwałtownego spadku wydatków konsumenckich i prywatnych inwestycji. Wzrost do 2,5\% może pojawić się w 2021 roku. Fitch Ratings oczekuje recesji we wszystkich głównych gospodarkach krajów rozwijających się. W szczególności sektor usług ponosi większość ciężaru spadających wydatków konsumenckich. PMI usług wszystkich krajów rozwiniętych spadł w marcu znacznie poniżej poziomu 50 - do 39,8 w Stanach Zjednoczonych, 33,8 w Japonii, 31,7 w Niemczech. W USA w marcu produkcja 
przemysłowa odnotowała najwyższy miesięczny spadek od końca II wojny światowej; sprzedaż spadła najbardziej od 1992 roku, a liczba zasiłków dla bezrobotnych wzrosła w drugim tygodniu kwietnia o 5,2 miliona, osiągając 22 miliony od początku kryzysu. Gwałtowne zaostrzenie globalnych warunków finansowych skłoniło banki centralne gospodarek rozwiniętych do złagodzenia polityki pieniężnej do poziomów niespotykanych od czasu światowego kryzysu finansowego w 2009 roku. W tabeli 2 zaprezentowano zmiany stóp procentowych w wybranych krajach.

Polityka fiskalna odgrywa ważną rolę we wspieraniu działalności gospodarczej w tym roku. Obawy dotyczące stabilności długu publicznego będą tymczasowe i oczekuje się gwałtownego rozszerzenia deficytu budżetowego i znacznego wzrostu poziomu długu publicznego. Wykorzystano rekordowe bodźce polityki fiskalnej (odpowiadające około 10\% PKB), aby złagodzić efekt COVID-19. Nawet kraje, w których słaby stan finansów publicznych lub narzucone ograniczenia polityczne zwykle zapobiegały znacznemu pogłębieniu długu publicznego (szczególnie w strefie euro), zastosowały zestaw narzędzi fiskalnych, aby stymulować gospodarkę. Niektóre kraje zapewne będą korzystały z kolejnych narzędzi fiskalnych (zob. tabela 3).

Tabela 3. Zastosowane narzędzia polityki fiskalnej w wybranych krajach

\begin{tabular}{|c|c|c|}
\hline Kraj & Zastosowane narzędzia fiskalne & Data \\
\hline $\begin{array}{l}\text { Stany } \\
\text { Zjednoczone }\end{array}$ & $\begin{array}{l}\text { Senat USA uchwala plan pomocy w wysokości } 484 \text { miliardów } \\
\text { dolarów, który obejmuje pomoc dla małych firm i szpitali, a tak- } \\
\text { że fundusze na rozszerzenie testów koronawirusa. }\end{array}$ & 21.04 .2020 \\
\hline $\begin{array}{l}\text { Korea } \\
\text { Południowa }\end{array}$ & $\begin{array}{l}\text { Rząd dokona awaryjnych płatności gotówkowych na rzecz } \\
\text { wszystkich, z wyjątkiem najbogatszych rodzin, o łącznej warto- } \\
\text { ści } 9,1 \text { biliona wonów ( } 7,5 \text { miliarda dolarów), opracowując drugi } \\
\text { dodatkowy budżet w kwietniu. Początkowy budżet dodatkowy } \\
\text { o wartości } 11,7 \text { trylionów wonów; } 50 \text { bilionów wonów w finanso- } \\
\text { waniu awaryjnym dla małych firm; kluczowe zasady przepływu } \\
\text { kapitału zostały tymczasowo rozluźnione, aby zachęcić lokalne } \\
\text { instytucje finansowe do dostarczania większej ilości dolarów. }\end{array}$ & 15.04 .2020 \\
\hline Stefa euro & $\begin{array}{l}\text { Ministrowie finansów Unii Europejskiej zgadzają się na wspar- } \\
\text { cie o wartości pół biliona euro, dzięki czemu całkowita reakcja } \\
\text { fiskalna UE na epidemię wyniesie } 3,2 \text { biliona euro. } 100 \text { miliardów } \\
\text { euro zostanie przeznaczone na program subsydiowania płac, aby } \\
\text { firmy mogły skrócić godziny pracy, a nie likwidować miejsca pra- } \\
\text { cy. Europejski Bank Inwestycyjny zintensyfikuje akcję kredytową } \\
\text { dla przedsiębiorstw o wartości } 200 \text { miliardów euro, a fundusz po- } \\
\text { mocowy Europejskiego Mechanizmu Stabilności (ESM) w strefie } \\
\text { euro udostępni rządom } 240 \text { miliardów euro taniego kredytu. }\end{array}$ & 9.04 .2020 \\
\hline $\begin{array}{l}\text { Korea } \\
\text { Południowa }\end{array}$ & $\begin{array}{l}\text { Prezydent Korei Południowej Mun Jae-in powiedział, że rząd } \\
\text { udostępni dodatkowe } 36 \text { trylionów wonów z tanich pożyczek } \\
\text { eksporterom dotkniętym przez koronawirusa. Mun powiedział } \\
\text { również, że wprowadzone zostaną nowe środki o wartości } 17,7 \\
\text { trylionów wonów, aby zwiększyć konsumpcję i wspierać popyt } \\
\text { wewnętrzny. }\end{array}$ & 8.04 .2020 \\
\hline
\end{tabular}




\begin{tabular}{|c|c|c|}
\hline $\begin{array}{l}\text { Korea } \\
\text { Południowa }\end{array}$ & $\begin{array}{l}\text { Korea Południowa podwoiła planowany pakiet ratowania gospo- } \\
\text { darki do } 100 \text { trylionów wonów. Pakiet obejmuje } 29,1 \text { biliona wo- } \\
\text { nów pożyczek dla małych i średnich przedsiębiorstw, a kolejne } \\
20 \text { trylionów wonów zostanie przeznaczone na zakup obligacji } \\
\text { korporacyjnych i papierów komercyjnych spółek zagrożonych } \\
\text { kryzysem kredytowym. }\end{array}$ & 7.04 .2020 \\
\hline Japonia & $\begin{array}{l}\text { Rząd zatwierdził bezprecedensowy pakiet bodźców ekonomicz- } \\
\text { nych w wysokości } 20 \% \text { produkcji gospodarczej. Pakiet wynosi } \\
108 \text { trylionów jenów ( } 993 \text { miliardy dolarów) i obejmuje wypłaty } \\
\text { gotówki o wartości ponad } 6 \text { trylionów jenów dla gospodarstw } \\
\text { domowych oraz małych i średnich firm. }\end{array}$ & 7.04.2020 \\
\hline Włochy & $\begin{array}{l}\text { Dekretem nadzwyczajnym zatwierdzono pakiet o wartości po- } \\
\text { nad } 400 \text { miliardów euro, który zaoferuje przedsiębiorstwom } \\
\text { płynność. }\end{array}$ & 6.04 .2020 \\
\hline $\begin{array}{l}\text { Republika } \\
\text { Południowej } \\
\text { Afryki }\end{array}$ & $\begin{array}{l}\text { RPA przeznaczy } 1,2 \text { miliarda rand ( } 66 \text { milionów dolarów) na } \\
\text { pomoc drobnym rolnikom w staraniach o wsparcie produkcji } \\
\text { żywności. }\end{array}$ & 6.04 .2020 \\
\hline Brazylia & $\begin{array}{l}\text { Rząd Brazylii uruchamia program o wartości } 51 \text { miliardów re- } \\
\text { ali, który pozwoli firmom dotkniętym kryzysem koronawirusa } \\
\text { zmniejszyć pensje i godziny pracy pracowników lub tymczasowo } \\
\text { zawiesić umowy w celu zachowania miejsc pracy. }\end{array}$ & 1.04 .2020 \\
\hline Indonezja & $\begin{array}{l}\text { Dżakarta ogłosiła dodatkowe } 24,9 \text { miliarda USD wydatków, } \\
\text { w tym obniżkę stawki podatku od osób prawnych o } 3 \text { punkty } \\
\text { procentowe do } 22 \% \text {. Inne środki polegały na rozszerzeniu po- } \\
\text { mocy społecznej, z korzyścią dla } 10 \text { milionów gospodarstw do- } \\
\text { mowych, pomocy żywnościowej oraz zniżkach i zwolnieniach } \\
\text { taryfowych na energię elektryczną. }\end{array}$ & 31.03 .2020 \\
\hline Hiszpania & $\begin{array}{l}\text { Rząd zatwierdził pakiet pomocy w wysokości } 700 \text { milionów } \\
\text { euro, w tym środek mający na celu zawieszenie eksmisji gospo- } \\
\text { darstw domowych znajdujących się w trudnej sytuacji na sześć } \\
\text { miesięcy po zniesieniu stanu wyjątkowego. }\end{array}$ & 31.03 .2020 \\
\hline Kanada & $\begin{array}{l}\text { Ottawa pokryje do } 75 \% \text { wynagrodzeń osób pracujących dla ma- } \\
\text { łych i średnich przedsiębiorstw; } 55 \text { miliardów USD odroczeń } \\
\text { podatkowych dla firm i rodzin; pakiet pomocy w wysokości } \\
27 \text { miliardów USD dla pracowników i gospodarstw domowych } \\
\text { o niskich dochodach. }\end{array}$ & 30.03 .2020 \\
\hline Chiny & $\begin{array}{l}\text { Biuro Polityczne rządzącej partii komunistycznej oświadczyło, } \\
\text { że przyspieszy zmiany polityki makroekonomicznej i będzie } \\
\text { prowadzić bardziej proaktywną politykę fiskalną. Wymagało to } \\
\text { zwiększenia deficytu budżetowego, emisji większej liczby obliga- } \\
\text { cji lokalnych i krajowych, obniżenia stóp procentowych, opóź- } \\
\text { nienia spłaty kredytów, ograniczenia wąskich gardeł w łańcuchu } \\
\text { dostaw i zwiększenia konsumpcji. }\end{array}$ & 27.03 .2020 \\
\hline $\begin{array}{l}\text { Stany Zjedno- } \\
\text { czone }\end{array}$ & $\begin{array}{l}\text { Izba Reprezentantów Stanów Zjednoczonych przekazała pa- } \\
\text { kiet pomocowy o wartości } 2,2 \text { biliona USD, największy w hi- } \\
\text { storii, w tym fundusz o wartości } 500 \text { miliardów USD, który ma } \\
\text { pomóc przemysłom znajdującym się w trudnej sytuacji, oraz po- } \\
\text { równywalną kwotę na bezpośrednie płatności w wysokości do } \\
3000 \text { USD dla milionów amerykańskich rodzin. }\end{array}$ & 27.03 .2020 \\
\hline
\end{tabular}




\begin{tabular}{|c|c|c|}
\hline Strefa euro & $\begin{array}{l}\text { Rozważenie dopuszczenia zapobiegawczej linii kredytowej } \\
\text { o wartości } 2 \% \text { krajowego PKB z funduszu ratunkowego EMS. }\end{array}$ & 26.03 .2020 \\
\hline Indie & $\begin{array}{l}\text { Rząd federalny ogłosił plan stymulacyjny o wartości } 1,7 \text { biliona } \\
\text { rupii ( } 22 \text { miliardy dolarów) zapewniający bezpośrednie przelewy } \\
\text { gotówkowe i środki bezpieczeństwa żywności. }\end{array}$ & 26.03 .2020 \\
\hline Strefa euro & Zawieszenie limitów zaciągania pożyczek przez rząd UE. & 23.03 .2020 \\
\hline Niemcy & $\begin{array}{l}\text { Uzgodniony pakiet o wartości do } 750 \text { miliardów euro; } 100 \text { mi- } \\
\text { liardów euro na fundusz stabilności gospodarczej, który może } \\
\text { przyjmować bezpośrednie udziały w spółkach; } 100 \text { miliardów } \\
\text { euro kredytu dla banku rozwoju publicznego KfW na pożyczki } \\
\text { dla borykających się z trudnościami przedsiębiorstw; Fundusz } \\
\text { Stabilności zaoferuje } 400 \text { miliardów euro gwarancji kredytowych } \\
\text { w celu zabezpieczenia długu korporacyjnego zagrożonego nie- } \\
\text { wypłacalnością. }\end{array}$ & 23.03 .2020 \\
\hline Australia & $\begin{array}{l}66,1 \text { miliarda dolarów na pomoc dla przedsiębiorstw i dodatko- } \\
\text { we świadczenia socjalne; } 17,6 \text { miliarda dolarów na dotacje dla } \\
\text { uczniów, małych firm, emerytów i innych; } 130 \text { miliardów dola- } \\
\text { rów na subsydiowanie wynagrodzeń około } 6 \text { milionów ludzi. }\end{array}$ & 22.03.2020 \\
\hline Chiny & $\begin{array}{l}\text { Chiny ogłaszają tryliony juanów bodźca fiskalnego. Ma na celu } \\
\text { pobudzenie inwestycji infrastrukturalnych, wspieranych przez } \\
\text { aż } 2,8 \text { biliona juanów specjalnych obligacji samorządowych. } \\
\text { Wskaźnik deficytu budżetu krajowego może wzrosnąć do rekor- } \\
\text { dowych poziomów. }\end{array}$ & 19.03.2020 \\
\hline Francja & $\begin{array}{l}45 \text { miliardów euro środków kryzysowych, aby pomóc firmom } \\
\text { i pracownikom. }\end{array}$ & 17.03 .2020 \\
\hline Hiszpania & $\begin{array}{l}\text { Zatwierdzono pakiet o wartości } 200 \text { miliardów euro; połowa } \\
\text { z udzielonych przez państwo gwarancji kredytowych dla przed- } \\
\text { siębiorstw, a reszta, w tym pożyczki, to pomoc dla osób szczegól- } \\
\text { nie narażonych. }\end{array}$ & 17.03 .2020 \\
\hline Francja & $\begin{array}{l}\text { Gwarancje do } 300 \text { miliardów euro pożyczek korporacyjnych od } \\
\text { banków komercyjnych. }\end{array}$ & 16.03 .2020 \\
\hline Włochy & $\begin{array}{l}\text { Dekret nadzwyczajny o wartości } 25 \text { miliardów euro zawieszający } \\
\text { spłaty pożyczek i kredytów hipotecznych dla firm i rodzin oraz } \\
\text { zwiększający fundusze, aby pomóc firmom w wynagrodzeniu } \\
\text { pracowników tymczasowo zwolnionych. }\end{array}$ & 16.03 .2020 \\
\hline Brazylia & $\begin{array}{l}\text { Zwiększenie budżetu o } 150 \text { miliardów reali w celu wsparcia naj- } \\
\text { bardziej narażonej ludności i miejsc pracy; dekret prezydencki } \\
\text { ogłaszający sytuację nadzwyczajną na szczeblu krajowym, po- } \\
\text { zwalający rządowi znieść cele budżetowe i zwolnić środki budże- } \\
\text { towe. }\end{array}$ & 16.03 .2020 \\
\hline Wielka Brytania & $\begin{array}{l}\text { Ogłoszono plan stymulacyjny o wartości } 30 \text { miliardów funtów; } \\
330 \text { miliardów funtów gwarancji kredytowych dla przedsię- } \\
\text { biorstw; rząd zaproponował, że zapłaci } 80 \% \text { płac, jeśli personel } \\
\text { zwolni się, maksymalnie do } 2500 \text { funtów miesięcznie. Przedsię- } \\
\text { biorstwa mogą także tymczasowo zatrzymać } 30 \text { miliardów fun- } \\
\text { tów podatku VAT. }\end{array}$ & 11.03 .2020 \\
\hline
\end{tabular}

Źródło: opracowanie własne. 
Fitch Ratings zakłada, że zagregowany wzrost PKB w regionie gospodarek rozwijających się wyhamuje, co oznacza gwałtowny spadek PKB z 3,9\% w 2019 roku i wolniejszą reakcję niż podczas kryzysu w 2009 roku, kiedy PKB wzrósł o 2,6\%. Kraje rozwijające się, które nie doświadczają dużych ognisk wewnętrznych choroby, ucierpią w wyniku spadku globalnego popytu, zakłócenia łańcucha dostaw i niskich cen towarów. Sytuacja będzie się różnić w zależności od regionu. Podczas gdy efekty koronawirusa były po raz pierwszy odczuwalne w Azji, szybka polityka odpowiedzi na przykład w Chinach i Korei Południowej sugeruje, że Azja Wschodząca będzie rzeczywiście jednym $\mathrm{z}$ regionów osiągających lepsze wyniki w tym roku. Fitch Ratings oczekuje, że aktywność gospodarcza w całej Azji wzrośnie w 2020 roku o $1,3 \%$, podczas gdy w innych rejonach produkcja spadnie. Największe spadki wystąpią w Rumunii i Polsce, gdzie wzrost spadnie odpowiednio o 2,8\% i 4,4\%. Obie te gospodarki charakteryzują się bliskimi powiązaniami handlowymi i inwestycyjnymi z gospodarkami Europy Zachodniej. Spodziewana jest również recesja w Rosji w wysokości 2,4\%, na którą wpłynie zmniejszony popyt u głównych partnerów handlowych i niskie ceny ropy naftowej przy rozszerzających się środkach nadzwyczajnych w celu ograniczenia rozprzestrzeniania się wirusa. Duże bufory fiskalne przynajmniej zamortyzują pozycję zadłużenia.

Prognozy dotyczące rynku amerykańskiego sugerują, że gospodarka Stanów Zjednoczonych skurczy się o 3,7\% w 2020 roku, co stanowi silniejszy spadek niż w czasie globalnego kryzysu finansowego. Bieżąca sytuacja jest wynikiem spadku konsumpcji, inwestycji oraz wymiany handlowej. Obniżenie nakładów inwestycyjnych nastąpi przede wszystkim w przypadku małych firm, które aktualnie walczą o przetrwanie. Co więcej, do momentu gdy liczba nowych przypadków zakażeń osiągnęła szczyt, spadek był bardzo powolny, co mogło opóźnić ponowne otwarcie, a tym samym ożywienie gospodarki. Silny spadek PKB będzie miał również miejsce w Niemczech. Fitch Ratings szacuje obniżkę PKB o 5\%. Zgodnie z sugerowanymi w kwietniu odczytami indeksu PMI dla Niemiec blokady i ograniczenia w zakresie mobilności mają duży wpływ na działalność gospodarczą, szczególnie w sektorze usług. Podobna sytuacja zachodzi również w Wielkiej Brytanii $(-4,5 \%)$, przy czym dodatkowy wpływ mają rozmowy handlowe z Unią Europejską.

\subsection{Opis danych i metody badawczej}

Celem pracy jest zbadanie wpływu kryzysu finansowego wywołanego przez COVID-19 na zmiany nastawienia oraz credit ratingów prezentowanych przez największe agencje ratingowe. Postawiono hipotezę badawczą brzmiącą następująco: kryzys finansowy wywołany COVID-19 wpłynął negatywnie na zmiany nastawienia i credit ratingów krajów.

Aby przeprowadzić wspomnianą analizę, zgromadzono dane dotyczące długoterminowych i krótkoterminowych credit ratingów 225 krajów oraz nastawienia z bazy Thomson Reuters Database / Refinitiv od 1 stycznia 1990 do 1 maja 2020 
roku. Dane dotyczyły ratingów zobowiązań wyrażonych w walucie obcej. Dobór okresu podyktowany jest niską zmiennością ratingów - aby zgromadzić dane na 2010 rok trzeba było wykorzystać dłuższy horyzont czasowy. Do badania istotności czynników wpływających na credit ratingi posłużono się danymi pochodzącymi z bazy Międzynarodowego Funduszu Walutowego. Makroekonomiczne dane tej bazy oraz jej prognozy na lata 2020-2021 opublikowane zostały pod koniec kwietnia 2020 roku. Ze względu na charakter badań wykonano dekompozycję liniową credit ratingów (Chodnicka-Jaworska, 2019). Badanie przeprowadzono dla lat 2010-2021 w ujęciu rocznym.

Dobór zmiennych do modelu podyktowany jest dotychczasowymi badaniami dotyczącymi czynników wpływających na credit ratingi krajów. W tabeli 4 zaprezentowano determinanty credit ratingów krajów stosowane w pracach innych badaczy.

\section{Tabela 4. Przegląd badań dotyczących czynników wpływających na credit ratingi krajów}

\begin{tabular}{|c|c|}
\hline Autor & Zakres badania \\
\hline Alesina et al. (1992) & $\begin{array}{l}12 \text { krajów OECD, lata 1974-1989, wskaźnik wzrostu indeksu produkcji } \\
\text { przemysłowej, wskaźnik długu do PKB, akumulacja długów i termin za- } \\
\text { padalności długu. }\end{array}$ \\
\hline Cantor, Packer (1995) & $\begin{array}{l}49 \text { krajów, lata 1991-1995, PKB per capita, stopa wzrostu PKB, inflacja, ze- } \\
\text { wnętrzny dług publiczny, poziom wzrostu gospodarczego, historia upad- } \\
\text { łości. }\end{array}$ \\
\hline Haque et al. (1996) & $\begin{array}{l}60 \text { krajów rozwijających się, lata 1980-1993, rezerwy walutowe/import, sal- } \\
\text { do rachunku bieżącego/PKB, stopa wzrostu PKB, stopy procentowe, krajo- } \\
\text { wa lokalizacja regionalna, struktura eksportu, inflacja. }\end{array}$ \\
\hline Min (1998) & $\begin{array}{l}11 \text { krajów rozwijających się, lata 1991-1995, całkowite zadłużenie ze- } \\
\text { wnętrzne/PKB, spread emisyjny, rezerwy zagraniczne/PKB, obsługa zadłu- } \\
\text { żenia/eksport, dynamika importu, tempo wzrostu eksportu, aktywa zagra- } \\
\text { niczne netto, inflacja CPI, indeks terms of trade, nominalny kurs walutowy } \\
\text { skorygowany o CPI, dojrzałość i wielkość emitenta. }\end{array}$ \\
\hline Ferri et al. (1999) & $\begin{array}{l}17 \text { krajów, lata 1989-1998, zmienne: stopa wzrostu PKB, deficyt budżetowy, } \\
\text { bilans rachunków bieżących, zadłużenie zagraniczne, rezerwy walutowe. }\end{array}$ \\
\hline $\begin{array}{l}\text { Reisen, von Maltzan } \\
(1999)\end{array}$ & $\begin{array}{l}\text { Lata } 1989-1997 \text {, badania ratingów państw na rynkach wschodzących, } \\
\text { wpływ cykli koniunkturalnych na ratingi. }\end{array}$ \\
\hline Ades et al. (2000) & $\begin{array}{l}15 \text { krajów rozwijających się, lata 1996-2000, stopa wzrostu PKB, całkowita } \\
\text { zewnętrzna amortyzacja/rezerwy, całkowity dług zewnętrzny/PKB, saldo } \\
\text { fiskalne/PKB, eksport/PKB, LIBOR, historia upadłości. }\end{array}$ \\
\hline $\begin{array}{l}\text { Monfort, Mulder } \\
(2000)\end{array}$ & $\begin{array}{l}20 \text { krajów, czynniki wewnętrzne (np. historia inflacji, wskaźniki kryzysu) } \\
\text { i zewnętrzne determinanty (np. rezerwy walutowe, rachunek bieżący, sal- } \\
\text { do, eksport, warunki handlu). Poziom oceny w tych krajach mogą wyjaśnić } \\
\text { takie zmienne, jak: wskaźnik długu do eksportu, historia zmiany harmo- } \\
\text { nogramu, stopa eksportu, inflacja, udział inwestycji w PKB, wskaźniki kry- } \\
\text { zysu. }\end{array}$ \\
\hline $\begin{array}{l}\text { Nogués, Grandes } \\
(2001)\end{array}$ & $\begin{array}{l}\text { Argentyna, wskaźnik całkowitego zwrotu z inwestycji eMBI w Meksyku, } \\
\text { zadłużenie zagraniczne/eksport długu zagranicznego, stopa wzrostu PKB, } \\
\text { równowaga fiskalna, 30-letnia rentowność skarbu państwa (ujemna). }\end{array}$ \\
\hline
\end{tabular}




\begin{tabular}{|c|c|}
\hline Hu et al. (2002) & $\begin{array}{l}\text { Od } 12 \text { do } 92 \text { krajów, lata 1981-1998, dawna niewypłacalność, rezerwy, in- } \\
\text { flacja, stosunek długu/PKB, kraj nieprzemysłowy, obsługa długu/eksportu. }\end{array}$ \\
\hline Afonso (2003) & $\begin{array}{l}81 \text { krajów, } 2001 \text { rok, PKB per capita, zadłużenie zagraniczne, poziom roz- } \\
\text { woju gospodarczego, historia upadłości, realna stopa wzrostu, inflacja. }\end{array}$ \\
\hline Borio, Packer (2004) & $\begin{array}{l}52 \text { kraje, lata 1996-2000, PKB per capita, inflacja, stopa wzrostu PKB, in- } \\
\text { deks korupcji, indeks ryzyka politycznego, historia upadłości. }\end{array}$ \\
\hline Rowland, Torres (2004) & $\begin{array}{l}19 \text { krajów, lata 1998-2002, realna stopa wzrostu PKB, zadłużenie/PKB, re- } \\
\text { zerwy/PKB, historia upadłości, obsługa zadłużenia/eksport. }\end{array}$ \\
\hline $\begin{array}{l}\text { Bissoondoyal-Bheenick } \\
\text { (2005) }\end{array}$ & $\begin{array}{l}95 \text { krajów, lata 1995-1999, РKB per capita, inflacja, bilans fiskalny/PKB, } \\
\text { dług publiczny/PKB, rezerwy walutowe, rachunki bieżące/PKB, eksport } \\
\text { netto/PKB. }\end{array}$ \\
\hline $\begin{array}{l}\text { Bissoondoyal-Bheenick } \\
\text { et al. (2006) }\end{array}$ & $\begin{array}{l}\mathrm{PKB} \text {, inflacja, bezpośrednie zagraniczne inwestycje do PKB, rachunek bie- } \\
\text { żący do PKB, handel do PKB, rzeczywiste stopy procentowe i telefony ko- } \\
\text { mórkowe, które pokazują poziom zaawansowania technologicznego kraju. }\end{array}$ \\
\hline Depken et al. (2011) & $\begin{array}{l}\text { Korupcja (wskaźnik percepcji korupcji opublikowany przez Transparency } \\
\text { International), indeksy społecznościowe, wskaźniki polityki fiskalnej, rów- } \\
\text { nowaga budżetowa, dług publiczny, demokracja i środki z ropy naftowej } \\
\text { (kraj, w którym występuje produkcja ropy naftowej). }\end{array}$ \\
\hline Butler, Fauver (2006) & $\begin{array}{l}93 \text { krajów, } 2004 \text { rok, środowisko prawne, PKB per capita, inflacja, zadłuże- } \\
\text { nie zagraniczne/PKB, historia upadłości, wskaźnik niedorozwoju. }\end{array}$ \\
\hline Afonso et al. (2012) & $\begin{array}{l}\text { 1995-2005, PKB per capita, realna stopa wzrostu PKB, dług publiczny, efek- } \\
\text { tywność rządu, zadłużenie zagraniczne, rezerwy. }\end{array}$ \\
\hline Remolona et al. (2008) & $\begin{array}{l}26 \text { krajów rozwijających się, lata 1990-2005, nominalne PKB, PKB per ca- } \\
\text { pita, inflacja, bilans rachunków bieżących/PKB, zadłużenie zagraniczne/ } \\
\text { PKB, ryzyko polityczne, historia upadłości, kurs walutowy. }\end{array}$ \\
\hline $\begin{array}{l}\text { Hilscher, Nosbusch } \\
\text { (2010) }\end{array}$ & $\begin{array}{l}32 \text { kraje rozwijające się, lata } 1994-2007 \text {, zmienność terms of trade, dług } \\
\text { publiczny/PKB, rezerwy/PKB, }\end{array}$ \\
\hline Afonso et al. (2010) & $\begin{array}{l}130 \text { krajów, lata 1995-2005, PKB per capita, realna stopa wzrostu PKB, dług } \\
\text { publiczny, zagraniczny dług publiczny, przystąpienie do UE, historia upad- } \\
\text { łości. }\end{array}$ \\
\hline Hill et al. (2010) & $\begin{array}{l}129 \text { krajów, lata 1990-2006, rozpoczęcie okresu oglądania statusu, zmiany } \\
\text { stopy wzrostu PKB, kierunek ostatniej zmiany oceny i prawdopodobień- } \\
\text { stwa upadłości. }\end{array}$ \\
\hline Caceres et al. (2010) & $\begin{array}{l}10 \text { zaawansowanych gospodarczo krajów, lata 2005-2010, indeks globalnej } \\
\text { awersji do ryzyka, wskaźniki zwrotne, całkowity bilans, zadłużenie do PKB. }\end{array}$ \\
\hline $\begin{array}{l}\text { Jaramillo, Tejada } \\
\text { (2011) }\end{array}$ & $\begin{array}{l}35 \text { krajów rozwijających się, lata 1997-2010, VIX, stopa procentowa, zadłu- } \\
\text { żenie zagraniczne/PKB, dług krajowy/PKB, rezerwy/PKB, stopa wzrostu } \\
\text { PKB. }\end{array}$ \\
\hline Oliveira et al. (2012) & $\begin{array}{l}7 \text { krajów EMU, lata 2000-2010, stopa zwrotu z rynku akcji, stopa procen- } \\
\text { towa, inflacja, poziom długu publicznego, deficyt rachunków bieżących, } \\
\text { inwestycje rządowe, cykl koniunkturalny. }\end{array}$ \\
\hline Teker et al. (2012) & $\begin{array}{l}\text { 1998-2010, } 23 \text { kraje - } 13 \text { rozwiniętych i } 10 \text { rozwijających się, podział ze } \\
\text { względu na okres przed kryzysem i po kryzysie, członkowie BRIC, UE, } \\
\text { OPEC, kraje budujące statki i utrzymujące rezerwy. }\end{array}$ \\
\hline
\end{tabular}




\begin{tabular}{|c|c|}
\hline $\begin{array}{l}\text { Bozic, Magazzino } \\
\text { (2013) }\end{array}$ & $\begin{array}{l}139 \text { krajów, lata 1975-2010, PKB per capita, inflacja, stopa bezrobocia, } \\
\text { bilans fiskalny, zadłużenie zagraniczne, historia upadłości, stopa wzrostu } \\
\text { DNB, bilans rachunków bieżących. }\end{array}$ \\
\hline Chee et al. (2015) & $\begin{array}{l}53 \text { kraje, lata } 2000-2011 \text {, historia upadłości, zadłużenie/eksport, dług pub- } \\
\text { liczny/PKB, rezerwy walutowe/PKB, M2/PKB, eksport/PKB, PKB per capi- } \\
\text { ta, deflator PKB, realny kurs walutowy, realna stopa procentowa, poziom } \\
\text { rozwoju gospodarczego, indeks wolności gospodarczej. }\end{array}$ \\
\hline $\begin{array}{l}\text { Chodnicka-Jaworska } \\
\text { (2015) }\end{array}$ & $\begin{array}{l}45 \text { krajów, lata 2000-2012, PKB per capita, stopa wzrostu PKB, oszczędno- } \\
\text { ści podmiotów krajowych/PKB, eksport/PKB, import/PKB, saldo obrotów } \\
\text { bieżących/PKB, stopa oprocentowania obligacji skarbowych, zadłużenie } \\
\text { zagraniczne/DNB, FDI/PKB, terms of trade, stopa bezrobocia, CPI, M3/ } \\
\text { PKB, realny kurs walutowy. }\end{array}$ \\
\hline Yalta, Yalta (2018) & $\begin{array}{l}99 \text { krajów, lata 2000-2017, budżet do PKB, dług publiczny do PKB, PKB per } \\
\text { capita, stopa bezrobocia, stopa inflacji, kurs walutowy, stopa procentowa, } \\
\text { efektywność rządowa, konflikt narodowy, niewykonanie zobowiązania za } \\
10 \text { lat, kraj eksportujący paliwo, region. }\end{array}$ \\
\hline Luitel, Vanpee (2018) & $\begin{array}{l}26 \text { krajów, lata } 2000-2016 \text {, kryzys bankowy, PKB per capita, stopa wzrostu } \\
\text { PKB, stopa inflacji, stopa bezrobocia, historia upadłości, stabilność poli- } \\
\text { tyczna, saldo rachunków obrotów bieżących/PKB, rezerwy walutowe, in- } \\
\text { deks przestrzegania prawa, FDI/PKB. }\end{array}$ \\
\hline Li et al. (2019) & $\begin{array}{l}40 \text { krajów, lata 1990-2018, PKB na mieszkańca, suma eksportu i importu } \\
\text { do PKB, CPI, wskaźnik kredytu krajowego dla sektora prywatnego do PKB, } \\
\text { wskaźnik nakładów brutto na środki trwałe do PKB. }\end{array}$ \\
\hline $\begin{array}{l}\text { Chodnicka-Jaworska } \\
\text { (2019) }\end{array}$ & $\begin{array}{l}225 \text { krajów, lata 2010-2018, spłata zadłużenia do PKB, poziom równowagi } \\
\text { fiskalnej mierzony deficytem do PKB, wartość odsetek z tytułu zadłużenia } \\
\text { do przychodów, wartość rezerw walutowych do PKB, stopa inflacji, saldo } \\
\text { obrotów bieżących do PKB, luka finansowania, poziom inwestycji bezpo- } \\
\text { średnich do PKB, wartość PKB per capita, realna stopa wzrostu PKB, stopa } \\
\text { bezrobocia, historia upadłości kraju, liczba lat od ogłoszenia upadłości kra- } \\
\text { ju, aktywa banków do PKB, stopa kredytów do depozytów banków, wskaź- } \\
\text { nik wolności słowa, wskaźnik stabilności politycznej i braku przemocy, } \\
\text { indeks skuteczności rządu, indeks jakości regulacji, wskaźnik praworząd- } \\
\text { ności, wskaźnik kontroli korupcji, wskaźnik globalnej konkurencyjności. }\end{array}$ \\
\hline
\end{tabular}

Źródło: opracowanie własne.

Aby zbadać wpływ ogłoszenia COVID-19 na credit rating, wykorzystano zmienne zero-jedynkowe, gdzie 0 oznacza brak przypadków COVID-19, a 1 - wystąpienie przypadków tej choroby. Badanie przyprowadzono przy wykorzystaniu uogólnionych logitowych modeli panelowych. Została zaprezentowana uogólniona wersja modelu:

$$
y_{i t}^{*}=\beta x_{i t}^{\prime}+\gamma Z_{i t}+\varepsilon_{i t}
$$

gdzie:

$Y_{i t}^{*}$ to zmienna obserowalna mierząca credit rating kraju $i$ w czasie $t$; $X^{\prime}$ it to wektor zmiennych niezależnych; 
$\beta$ to wektor nieznanych parametrów;

$Z_{i t}$ to wektor zmiennych zerojedynkowych;

$\varepsilon_{i t}$ jest przypadkowym zaburzeniem, które ma rozkład normalny;

$y_{i t}^{*}$ jest związany z obserwowaną zmienną $y_{i}$, oznaczającą credit rating zdefiniowany w następujący sposób:

$$
\begin{aligned}
& y_{i}=-5 \text { if } y_{i}^{*}<\tau_{0} \\
& 0 \text { if } \varepsilon_{0}<y_{i}^{*}<\tau_{1} \\
& 5 \text { if } \varepsilon_{1}<y_{i}^{*}<\tau_{2} \\
& 10 \text { if } \varepsilon_{2}<y_{i}^{*}<\tau_{3} \\
& 15 \text { if } \varepsilon_{3}<y_{i}^{*}<\tau_{4} \\
& 20 \text { if } \varepsilon_{4}<y_{i}^{*}<\tau_{5} \\
& 100 \text { if } \varepsilon_{21}<y_{i}^{*}<0
\end{aligned}
$$

gdzie $\tau_{s}\left(\tau_{0}<\tau_{1}<\tau_{2}<\ldots<\tau_{22}\right)$ są znanymi parametrami progowymi, które należy oszacować. Następujący model można nazwać modelem uporządkowanym:

$$
y_{i t}^{*}=\beta F_{i t}^{\prime}+\gamma Z_{i t}+\delta(F * Z)_{i t}+\varepsilon_{i t}
$$

gdzie:

$y_{i t}$ oznacza credit rating kraju $i$ w czasie $t$ publikowany przez Moody's i S\&P;

$F_{i t}$ to wektor zmiennych niezależnych, to jest:

gdzie:

$$
F_{i t}=\left[\inf _{i t}, g o v_{i t}, \operatorname{deb}_{i t}, p k b_{i t}\right]
$$

inf $_{\text {it }}$ to stopa inflacji; gov it $_{\text {t }}$ to pożyczki netto sektora instytucji rządowych i samorządowych do PKB; deb $b_{i t}$ to dług publiczny do PKB; $p k b_{i t}$ to realna stopa wzrostu PKB; $Z_{i t}$ to wektor zmiennych zero-jedynkowych, gdzie $F_{i t}=\left[\operatorname{cov}_{i t}\right]$; gdy $\operatorname{cov}_{i}$ wynosi 1, oznacza wystąpienie przypadków COVID-19, a gdy wynosi 0, oznacza brak takich przypadków. 


\section{Wyniki badań}

Analizę rozpoczęto od badania zmienności ratingów poszczególnych agencji ratingowych w okresie badawczym w wyniku ogłoszenia przypadków COVID-19. Zmiany credit ratingów zaprezentowano w tabelach 5-7. Analiza danych wskazuje, że agencje ratingowe zaczynają obniżać noty w wyniku publikacji informacji na temat COVID-19 oraz związanej z tym sytuacji gospodarczej. Zmiany dotyczące ratingów nie mają charakteru masowego. Dotyczy to zarówno długo-, jak i krótkoterminowego ratingu. Zgodnie $\mathrm{z}$ danymi zaprezentowanymi $\mathrm{w}$ tabeli 5 Moody's w 2020 roku obniżył ocenę ośmiu krajom o jedną notę oraz trzem o trzy noty (pięć obniżek w 2019 roku). Nie ogłoszono żadnej decyzji na temat poprawy ratingu. Większość ratingów pozostaje bez zmian, tak jak w ubiegłych latach. Z kolei wyniki zaprezentowane w tabeli 6 dla S\&P sugerują większą obniżkę not. I tak w 2020 roku obniżono ratingi dwunastu krajów o jedną notę (w 2019 roku - dwóch krajów), dwóch krajów o dwie noty (w 2019 roku - jednego kraju), jednego kraju o trzy noty i jednego o pięć not (tak jak w 2019 roku). Ratingi dwóch krajów w 2020 roku zostały poprawione przez S\&P. Można zatem zauważyć, iż silniejsze zmiany w przypadku credit ratingów krajów w 2020 roku zaprezentował S\&P niż Moody’s.

Tabela 5. Zmiana długoterminowego credit ratingu emitenta publikowanego przez Moody’s dotycząca zobowiązań wyrażonych w walucie obcej

\begin{tabular}{|c|l|l|l|l|l|l|l|l|l|l|l|l|}
\hline $\begin{array}{l}\text { Rok/ } \\
\text { Zmiana }\end{array}$ & -10 & -7 & -6 & -5 & -4 & -3 & -2 & -1 & 0 & 1 & 2 & 3 \\
\hline 2011 & 1 & 1 & 1 & 0 & 1 & 3 & 3 & 6 & 82 & 7 & 0 & 0 \\
\hline 2012 & 0 & 0 & 1 & 2 & 1 & 1 & 0 & 12 & 78 & 12 & 0 & 0 \\
\hline 2013 & 0 & 0 & 0 & 0 & 0 & 3 & 5 & 5 & 93 & 3 & 1 & 1 \\
\hline 2014 & 0 & 0 & 0 & 0 & 0 & 1 & 1 & 11 & 89 & 10 & 3 & 2 \\
\hline 2015 & 0 & 0 & 0 & 0 & 0 & 0 & 3 & 8 & 96 & 10 & 1 & 0 \\
\hline 2016 & 0 & 0 & 0 & 0 & 1 & 3 & 4 & 19 & 88 & 3 & 2 & 0 \\
\hline 2017 & 0 & 0 & 0 & 0 & 0 & 0 & 4 & 14 & 90 & 11 & 2 & 0 \\
\hline 2018 & 0 & 0 & 0 & 0 & 0 & 0 & 3 & 10 & 99 & 9 & 1 & 0 \\
\hline 2019 & 0 & 0 & 0 & 0 & 0 & 1 & 1 & 5 & 105 & 9 & 2 & 0 \\
\hline 2020 & 0 & 0 & 0 & 0 & 0 & 3 & 0 & 8 & 116 & 0 & 0 & 0 \\
\hline
\end{tabular}

Źródło: opracowanie własne. 
Tabela 6. Zmiana długoterminowego credit ratingu emitenta publikowanego przez S\&P dotycząca zobowiązań wyrażonych w walucie obcej

\begin{tabular}{|c|c|c|c|c|c|c|c|c|c|c|c|c|c|c|c|c|c|c|c|}
\hline Rok/Zmiana & -95 & -70 & -45 & -40 & -35 & -30 & -25 & -20 & -15 & -10 & -5 & 0 & 5 & 10 & 15 & 20 & 25 & 35 & 95 \\
\hline 2011 & 0 & 1 & 1 & 0 & 0 & 0 & 0 & 0 & 4 & 2 & 16 & 73 & 16 & 2 & 0 & 0 & 0 & 0 & 0 \\
\hline 2012 & 0 & 0 & 0 & 1 & 0 & 1 & 1 & 0 & 0 & 5 & 13 & 85 & 8 & 1 & 0 & 1 & 0 & 0 & 0 \\
\hline 2013 & 1 & 0 & 1 & 0 & 0 & 1 & 0 & 1 & 0 & 2 & 13 & 89 & 7 & 0 & 0 & 0 & 1 & 0 & 0 \\
\hline 2014 & 0 & 0 & 0 & 0 & 0 & 1 & 0 & 1 & 1 & 2 & 14 & 89 & 7 & 3 & 0 & 0 & 0 & 0 & 1 \\
\hline 2015 & 0 & 0 & 0 & 0 & 0 & 0 & 0 & 0 & 0 & 3 & 16 & 86 & 14 & 0 & 1 & 0 & 0 & 0 & 0 \\
\hline 2016 & 0 & 0 & 0 & 0 & 1 & 0 & 0 & 2 & 1 & 6 & 15 & 86 & 9 & 0 & 0 & 0 & 1 & 0 & 0 \\
\hline 2017 & 0 & 0 & 0 & 0 & 0 & 0 & 0 & 0 & 1 & 1 & 17 & 89 & 10 & 2 & 0 & 1 & 0 & 0 & 0 \\
\hline 2018 & 0 & 0 & 0 & 0 & 0 & 0 & 0 & 1 & 0 & 2 & 6 & 96 & 13 & 1 & 0 & 0 & 0 & 1 & 0 \\
\hline 2019 & 0 & 0 & 0 & 0 & 0 & 0 & 1 & 0 & 0 & 1 & 2 & 97 & 19 & 0 & 0 & 1 & 1 & 0 & 0 \\
\hline 2020 & 0 & 0 & 0 & 0 & 0 & 0 & 1 & 0 & 1 & 2 & 12 & 103 & 2 & 0 & 0 & 0 & 0 & 0 & 0 \\
\hline
\end{tabular}

Źródło: opracowanie własne.

Analiza ratingów krótkoterminowych nadawanych przez S\&P (zob. tabela 7) nie wykazała szczególnych zmian. Tak jak w poprzednich przypadkach w 2020 roku widoczne są znacznie mniejsza liczba popraw credit ratingów i nieco więcej obniżek not. Zmiany te nie są jednak silne w porównaniu z oczekiwaniami wynikającymi z krótkoterminowego charakteru ratingu.

Tabela 7. Zmiana krótkoterminowego credit ratingu emitenta publikowanego przez S\&P dotycząca zobowiązań wyrażonych w walucie obcej

\begin{tabular}{|c|c|c|c|c|c|c|c|c|c|c|c|c|c|}
\hline Rok/Zmiana & -100 & $-73,3$ & $-46,6$ & -40 & $-33,3$ & -20 & $-11,6$ & 6,6 & 13,3 & 20 & 33,3 & 40 & 100 \\
\hline 2011 & 0 & 1 & 0 & 2 & 3 & 3 & 1 & 3 & 2 & 1 & 1 & 0 & 0 \\
\hline 2012 & 0 & 0 & 2 & 0 & 0 & 3 & 4 & 3 & 1 & 9 & 6 & 0 & 0 \\
\hline 2013 & 1 & 0 & 0 & 2 & 1 & 1 & 0 & 1 & 1 & 1 & 1 & 1 & 0 \\
\hline 2014 & 0 & 0 & 0 & 1 & 3 & 3 & 0 & 1 & 1 & 3 & 0 & 0 & 1 \\
\hline 2015 & 0 & 0 & 0 & 0 & 1 & 4 & 2 & 4 & 0 & 2 & 1 & 0 & 0 \\
\hline 2016 & 0 & 0 & 0 & 1 & 2 & 4 & 3 & 0 & 1 & 1 & 1 & 1 & 0 \\
\hline 2017 & 0 & 0 & 0 & 0 & 4 & 1 & 2 & 3 & 3 & 3 & 1 & 0 & 0 \\
\hline 2018 & 0 & 0 & 0 & 0 & 0 & 0 & 0 & 2 & 2 & 2 & 2 & 1 & 0 \\
\hline 2019 & 0 & 0 & 0 & 0 & 2 & 0 & 0 & 3 & 1 & 5 & 0 & 1 & 0 \\
\hline 2020 & 0 & 0 & 0 & 1 & 3 & 1 & 0 & 2 & 0 & 0 & 0 & 0 & 0 \\
\hline
\end{tabular}

Źródło: opracowanie własne. 
Analiza outlooku Moody's zaprezentowana w tabeli 8 wskazuje z kolei, że agencja zamierza obniżać credit ratingi. W zaistniałej sytuacji obserwuje się znaczny wzrost liczby zapowiedzi dotyczących obniżki not w porównaniu do lat ubiegłych. Prezentowana sytuacja odnosi się do długoterminowych ocen - outlook oznacza nastawienie długoterminowe.

Tabela 8. Zmiana outlooku publikowanego przez Moody's

\begin{tabular}{|c|c|c|c|}
\hline Rok/Zmiana & -1 & 0 & 1 \\
\hline 2010 & 18 & 92 & 9 \\
\hline 2011 & 23 & 81 & 13 \\
\hline 2012 & 34 & 76 & 6 \\
\hline 2013 & 29 & 83 & 7 \\
\hline 2014 & 16 & 98 & 7 \\
\hline 2015 & 28 & 87 & 7 \\
\hline 2016 & 30 & 88 & 14 \\
\hline 2017 & 15 & 93 & 17 \\
\hline 2018 & 12 & 97 & 13 \\
\hline 2019 & 13 & 97 & 5 \\
\hline 2020 & 26 & 94 & \\
\hline
\end{tabular}

Źródło: opracowanie własne.

W następnym etapie postanowiono zweryfikować istotność czynników na credit ratingi krajów poza informacjami dotyczącymi COVID-19. Wyniki analiz zaprezentowano w tabelach 9-11. Sprawdzono korelację, stacjonarność oraz kointegrację. Wyniki badań dla determinant długoterminowych credit ratingów Moody's przedstawiono w tabeli 9. Przeprowadzone estymacje wskazują na brak wpływu występowania COVID-19 na długoterminowy credit rating krajów. Przed kryzysem COVID-19 istotny negatywny wpływ na credit rating miała wartość długu publicznego. Im był on wyższy, tym noty krajów spadały. Taka zależność była prezentowana w dotychczasowych badaniach (Cantor, Packer, 1995; Bissoondoyal-Bheenick, 2005; Bissoondoyal-Bheenick et al., 2006; Oliveira et al., 2012; Teker et al., 2012; Bozic, Magazzino, 2013; Chodnicka-Jaworska, 2015, 2019; Yalta, Yalta, 2018; Luitel, Vanpee, 2018; Li et al., 2019). Podczas analizowanego kryzysu zmienna ta nie posiada istotnego wpływu. Może mieć to związek z powszechnym zadłużaniem się krajów i luzowaniem polityki fiskalnej, aby złagodzić następstwa COVID-19. Podobny związek obserwuje się w przypadku stopy wzrostu PKB. Dotychczasowe badania sugerowały, że im szybciej rozwijający się kraj, tym wyższy powinien być credit rating (Ferri et al., 1999; Cantor, Packer, 1995; Afonso et al., 2010, 2012; Hill et al., 2010; Oliveira et al., 2012; Bozic, Magazzino, 2013; Chodnicka-Jaworska, 2019). Wskaźnik ten wpływał nawet w $80 \%$ na zmiany credit ratingów krajów 
(Cantor, Packer, 1995). Prezentowane wyniki potwierdzają tę zależność. Zmienna ta wywierała istotny wpływ przede wszystkim przed kryzysem. W czasie pandemii COVID-19 takiego związku się nie obserwuje. Może to wynikać z globalnego spadku PKB. Ponieważ sytuacja ta dotyczy wszystkich krajów, sam spadek popytu nie jest tak istotny. Uwzględnienie COVID-19 sugeruje z kolei istotność kredytowania kraju. Środki te mogą bowiem posłużyć do pobudzania gospodarki w przyszłości. Silnie rosnąca inflacja nie jest zjawiskiem pozytywnym, jednak w okresie pandemii COVID-19 zdaje się nie mieć istotnego znaczenia, co staje w sprzeczności z dotychczasowymi badaniami w tym zakresie (Yalta, Yalta, 2018; Li et al., 2019; Chodnicka-Jaworska, 2019).

Tabela 9. Determinanty wpływające na zmianę długoterminowego credit ratingu emitenta publikowanego przez Moody's dotyczącą zobowiązań wyrażonych w walucie obcej

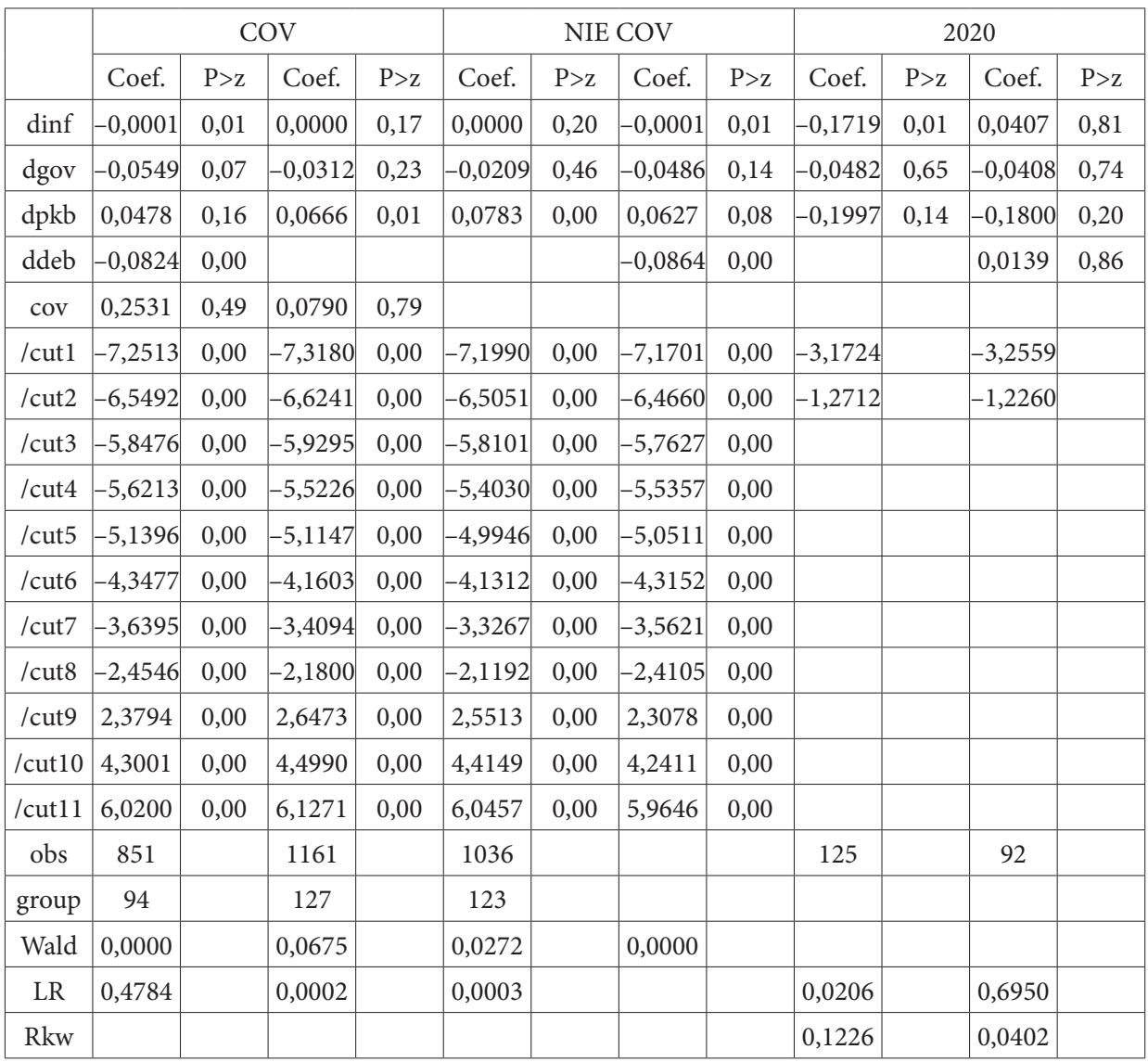

Legenda: obs - liczba obserwacji, group - liczba krajów, Wald - test Walda, Rkw - skorygowany R kwadrat, LR - test ilorazu wiarygodności, COV - badanie przy uwzględnieniu wpływu wystąpienia COVID-19, NIE COV - badanie dla okresu przed wystąpieniem COVID-19, 2020 - okres występowania COVID-19.

Źródło: opracowanie własne. 
W przypadku czynników wpływających na długoterminowy credit rating kraju publikowany przez S\&P dostrzeżono istotny statystycznie wpływ COVID-19 na badane zjawisko (zob. tabela 10). Okazuje się, że wystąpienie pandemii przyczyniło się do obniżki ratingów. Potwierdza to analizy przeprowadzone dla zmian credit ratingów. Siła wpływu nie jest duża, ale można domniemywać jej zwiększenia w najbliższym czasie. Ponadto występuje silny wpływ zadłużenia krajów w okresie przed wystąpieniem pandemii, co świadczy o podobieństwie oceny do not Moody’s i potwierdza dotychczasowe badania (Ferri et al., 1999; Cantor, Packer, 1995; Afonso et al., 2010, 2012; Bozic, Magazzino, 2013; Chodnicka-Jaworska, 2019). W okresie pandemii, zgodnie $\mathrm{z}$ analizą danych liczbowych, dochodzi do powszechnego zadłużania się krajów w celu pozyskania środków finansowych na ograniczenie skutków COVID-19 dla gospodarek. Rosnąca inflacja jest wyjątkowo niebezpieczna w dobie pandemii. Może mieć to związek z luzowaniem polityki pieniężnej. Rosnąca realna stopa wzrostu PKB jest również szczególnie pożądana w okresie kryzysu wywołanego COVID-19. Badana zależność potwierdza dotychczasowe badania (Ferri et al., 1999; Cantor, Packer, 1995; Oliveira et al., 2012; Bozic, Magazzino, 2013; Chodnicka-Jaworska, 2019). W prognozach na lata 2020 i 2021 oczekuje się powszechnego spadku stopy wzrostu PKB. W związku z tym kraje, które odnotowują wzrost badanej zmiennej, traktowane są jako stabilne gospodarczo.

Tabela 10. Determinanty wpływające na zmianę długoterminowego credit ratingu emitenta publikowanego przez S\&P dotyczącą zobowiązań wyrażonych w walucie obcej

\begin{tabular}{|c|c|c|c|c|c|c|c|c|c|c|c|c|}
\hline & \multicolumn{4}{|c|}{$\mathrm{COV}$} & \multicolumn{4}{|c|}{ NIE COV } & \multicolumn{4}{|c|}{2020} \\
\hline & Coef. & $\mathrm{P}>\mathrm{Z}$ & Coef. & $\mathrm{P}>\mathrm{z}$ & Coef. & $\mathrm{P}>\mathrm{z}$ & Coef. & $\mathrm{P}>\mathrm{z}$ & Coef. & $\mathrm{P}>\mathrm{z}$ & Coef. & $\mathrm{P}>\mathrm{Z}$ \\
\hline $\operatorname{dinf}$ & 0,0000 & 0,53 & 0,0000 & 0,78 & 0,0000 & 0,63 & 0,0000 & 0,76 & $-0,2021$ & 0,26 & $-0,2499$ & 0,00 \\
\hline dgov & 0,0131 & 0,65 & 0,0167 & 0,23 & 0,0279 & 0,37 & 0,0192 & 0,17 & 0,0199 & 0,82 & 0,0293 & 0,67 \\
\hline dpkb & 0,0613 & 0,05 & 0,0077 & 0,32 & 0,0943 & 0,00 & 0,0087 & 0,27 & 0,3253 & 0,02 & 0,1109 & 0,03 \\
\hline ddeb & $-0,0919$ & 0,00 & & & $|-0,0961|$ & 0,00 & & & $-0,0314$ & 0,56 & & \\
\hline cov & $-0,7534$ & 0,03 & $\mid-0,2277$ & 0,32 & & & & & & & & \\
\hline /cut1 & $\mid-7,2896$ & 0,00 & $\mid-7,3009$ & 0,00 & $-7,2044$ & 0,00 & $\mid-7,1378$ & 0,00 & $\mid-3,3418$ & & $\mid-5,2484$ & \\
\hline /cut2 & $-6,5876$ & 0,00 & $\mid-6,1994$ & 0,00 & $\mid-6,4971$ & 0,00 & $-6,0354$ & 0,00 & $\mid-0,8827$ & & $-4,4997$ & \\
\hline /cut3 & $-5,6618$ & 0,00 & $-5,9109$ & 0,00 & $-5,5665$ & 0,00 & $-5,7466$ & 0,00 & 6,0003 & & $\mid-3,4487$ & \\
\hline /cut4 & $-5,3212$ & 0,00 & $|-5,6869|$ & 0,00 & $\mid-5,3815$ & 0,00 & $-5,5225$ & 0,00 & & & $\mid-1,5490$ & \\
\hline /cut5 & $-5,1839$ & 0,00 & $-5,2144$ & 0,00 & $-5,2221$ & 0,00 & $-5,0494$ & 0,00 & & & 4,9080 & \\
\hline /cut6 & $\mid-4,6706$ & 0,00 & $\mid-4,8930$ & 0,00 & $-4,6451$ & 0,00 & $-4,8240$ & 0,00 & & & & \\
\hline /cut7 & $-3,8425$ & 0,00 & $\mid-4,5780$ & 0,00 & $\mid-3,7574$ & 0,00 & $-4,4823$ & 0,00 & & & & \\
\hline /cut8 & $-2,3025$ & 0,00 & $-4,1403$ & 0,00 & $-2,2484$ & 0,00 & $-4,0672$ & 0,00 & & & & \\
\hline /cut9 & 2,0806 & 0,00 & $-3,4176$ & 0,00 & 2,0048 & 0,00 & $-3,3447$ & 0,00 & & & & \\
\hline /cut10 & 4,3518 & 0,00 & $\mid-1,9918$ & 0,00 & 4,2852 & 0,00 & $-1,9249$ & 0,00 & & & & \\
\hline
\end{tabular}




\begin{tabular}{|c|c|c|c|c|c|c|c|c|c|c|c|c|}
\hline /cut11 & 5,4712 & 0,00 & 2,3182 & 0,00 & 5,4069 & 0,00 & 2,2351 & 0,00 & & & & \\
\hline /cut12 & 5,7633 & 0,00 & 4,5232 & 0,00 & 5,6993 & 0,00 & 4,4266 & 0,00 & & & & \\
\hline /cut13 & 6,8710 & 0,00 & 5,2957 & 0,00 & 6,8078 & 0,00 & 5,1993 & 0,00 & & & & \\
\hline /cut14 & & & 5,4506 & 0,00 & & & 5,3544 & 0,00 & & & & \\
\hline /cut15 & & & 6,1460 & 0,00 & & & 6,0501 & 0,00 & & & & \\
\hline /cut16 & & & 7,2457 & 0,00 & & & 7,1501 & 0,00 & & & & \\
\hline obs & 868 & & 1173 & & 780 & & 1054 & & 88 & & 119 & \\
\hline group & 90 & & 121 & & 90 & & 121 & & & & & \\
\hline Wald & 0,0000 & & 0,0000 & & 0,0000 & & 0,1725 & & & & & \\
\hline LR & 0,1628 & & 0,0000 & & 0,3221 & & 0,0004 & & 0,0266 & & 0,0011 & \\
\hline Rkw & & & & & & & & & 0,1366 & & 0,1179 & \\
\hline
\end{tabular}

Legenda: obs - liczba obserwacji, group - liczba krajów, Wald - test Walda, Rkw - skorygowany $\mathrm{R}$ kwadrat, LR - test ilorazu wiarygodności, COV - badanie przy uwzględnieniu wpływu wystąpienia COVID-19, NIE COV - badanie dla okresu przed wystąpieniem COVID-19, 2020 - okres występowania COVID-19.

Źródło: opracowanie własne.

Badanie wpływu COVID-19 na zmiany krótkoterminowych credit ratingów S\&P również dowiodło braku istotności wpływu pandemii na ich korektę (zob. tabela 11). Warto zauważyć, że głównym czynnikiem oddziałującym na krótkoterminowe noty jest zmiana poziomu zadłużenia kraju. Pozostałe zmienne nie oddziałują istotnie. Badane zależności potwierdzone zostały analizą empiryczną zmian ratingów przedstawioną $\mathrm{w}$ tabeli 7 . Zmiana krótkoterminowych credit ratingów ma charakter ad hoc, w związku z tym zasadny jest brak zależności obserwowanych dla ratingów długoterminowych.

Tabela 11. Determinanty wpływające na zmianę krótkoterminowego credit ratingu emitenta publikowanego przez S\&P dotyczącą zobowiązań wyrażonych w walucie obcej

\begin{tabular}{|c|c|c|c|c|c|c|c|c|c|c|c|c|}
\hline & \multicolumn{5}{|c}{ COV } & \multicolumn{4}{c|}{ NIE COV } & \multicolumn{4}{c|}{2020} \\
\cline { 2 - 15 } & Coef. & P $>$ z & Coef. & P $>$ z & Coef. & P $>$ z & Coef. & P $>$ z & Coef. & P $>$ z & Coef. & P $>$ z \\
\hline dinf & 0,0000 & 0,22 & 0,0000 & 0,90 & 0,0000 & 0,26 & 0,0000 & 0,885 & $-0,2258$ & 0,00 & $-0,2612$ & 0,57 \\
\hline dgov & 0,0352 & 0,36 & 0,0195 & 0,27 & 0,0432 & 0,28 & 0,0206 & 0,241 & 0,0601 & 0,56 & $-0,0027$ & 0,99 \\
\hline dpkb & $-0,0193$ & 0,65 & 0,0055 & 0,54 & $-0,0017$ & 0,97 & 0,0057 & 0,522 & $-0,1062$ & 0,45 & $-0,1606$ & 0,57 \\
\hline ddeb & $-0,0679$ & 0,00 & & & $-0,0625$ & 0,00 & & & & & $-0,1885$ & 0,14 \\
\hline cov & 0,2033 & 0,66 & $-0,3051$ & 0,32 & & & & & & & & \\
\hline /cut1 & $-7,0440$ & 0,00 & $-7,1273$ & 0,00 & $-6,8855$ & 0,00 & $-6,9669$ & 0,000 & $-5,2428$ & & $-6,2817$ & \\
\hline /cut2 & $-6,3484$ & 0,00 & $-6,4327$ & 0,00 & $-6,1896$ & 0,00 & $-6,2719$ & 0,000 & $-3,5379$ & & $-5,4319$ & \\
\hline /cut3 & $-5,9409$ & 0,00 & $-6,0262$ & 0,00 & $-5,7818$ & 0,00 & $-5,8652$ & 0,000 & $-3,2359$ & & & \\
\hline /cut4 & $-5,2430$ & 0,00 & $-5,5136$ & 0,00 & $-5,2675$ & 0,00 & $-5,3523$ & 0,000 & $-2,9782$ & & & \\
\hline
\end{tabular}




\begin{tabular}{|c|c|c|c|c|c|c|c|c|c|c|}
\hline /cut5 & $-4,1745$ & 0,00 & $-4,8160$ & 0,00 & $-4,1431$ & 0,00 & $-4,7605$ & 0,000 & & \\
\hline /cut6 & $-3,8126$ & 0,00 & $-4,7198$ & 0,00 & $-3,7423$ & 0,00 & $-4,6541$ & 0,000 & & \\
\hline /cut7 & $-3,5762$ & 0,00 & $-3,7345$ & 0,00 & $-3,4869$ & 0,00 & $-3,7234$ & 0,000 & & \\
\hline /cut8 & $-3,3519$ & 0,00 & $-3,4031$ & 0,00 & $-3,2479$ & 0,00 & $-3,3771$ & 0,000 & & \\
\hline /cut9 & $-3,3232$ & 0,00 & $-3,2355$ & 0,00 & $-3,2175$ & 0,00 & $-3,1877$ & 0,000 & & \\
\hline /cut10 & $-3,2952$ & 0,00 & $-3,0154$ & 0,00 & $-3,1879$ & 0,00 & $-2,9439$ & 0,000 & & \\
\hline /cut11 & $-3,1409$ & 0,00 & $-2,9974$ & 0,00 & $-3,0253$ & 0,00 & $-2,9242$ & 0,000 & & \\
\hline /cut12 & 2,7662 & 0,00 & $-2,9116$ & 0,00 & 2,6812 & 0,00 & $-2,8487$ & 0,000 & & \\
\hline /cut13 & 2,9312 & 0,00 & $-2,8166$ & 0,00 & 2,8470 & 0,00 & $-2,7441$ & 0,000 & & \\
\hline /cut14 & 2,9568 & 0,00 & 2,8573 & 0,00 & 2,8727 & 0,00 & 2,7841 & 0,000 & & \\
\hline /cut15 & 3,2530 & 0,00 & 2,9836 & 0,00 & 3,1701 & 0,00 & 2,9109 & 0,000 & & \\
\hline /cut16 & 3,4785 & 0,00 & 3,0028 & 0,00 & 3,3963 & 0,00 & 2,9302 & 0,000 & & \\
\hline /cut17 & 4,4266 & 0,00 & 3,2651 & 0,00 & 4,3463 & 0,00 & 3,1934 & 0,000 & & \\
\hline /cut18 & 6,0599 & 0,00 & 3,4248 & 0,00 & 5,9808 & 0,00 & 3,3534 & 0,000 & & \\
\hline /cut19 & 6,7543 & 0,00 & 4,2541 & 0,00 & 6,6753 & 0,00 & 4,1841 & 0,000 & & \\
\hline /cut20 & & & 5,6515 & 0,00 & & & 5,5823 & 0,000 & & \\
\hline /cut21 & & & 5,9401 & 0,00 & & & 5,8710 & 0,000 & & \\
\hline obs & 869 & & 1174 & & 781 & & 1055 & & 119 & 88 \\
\hline group & 90 & & 121 & & 90 & & 121 & & & \\
\hline Wald & 0,0013 & & 0,2835 & & 0,0019 & & 0,3702 & & & \\
\hline LR & & & & & & & & & 0,1691 & 0,1999 \\
\hline Rkw & & & & & & & & & 0,0143 & 0,274 \\
\hline
\end{tabular}

Legenda: obs - liczba obserwacji, group - liczba krajów, Wald - test Walda, Rkw - skorygowany R kwadrat, LR - test ilorazu wiarygodności, COV - badanie przy uwzględnieniu wpływu wystąpienia COVID-19, NIE COV - badanie dla okresu przed wystąpieniem COVID-19, 2020 - okres występowania COVID-19.

Źródło: opracowanie własne.

Badanie zostało zakończone analizą czynników wpływających na nastawienie (ang. outlook) kraju (zob. tabela 12). Zmiana nastawienia podyktowana jest w znacznej mierze pandemią. Na prezentowaną sytuację oddziałuje również zadłużenie, jednak - tak jak w poprzednich przypadkach - jego wielkość nie jest istotna $\mathrm{w}$ czasie pandemii. Zmiana nastawienia mocno związana jest $\mathrm{z}$ prognozowaną stopą wzrostu PKB. W zaistniałej sytuacji można domniemywać, że agencje Moody's i S\&P obserwują przede wszystkim stopę wzrostu PKB przy analizie zmian credit ratingów. 
Tabela 12. Determinanty wpływające na zmianę outlooku publikowanego przez Moody's i S\&P

\begin{tabular}{|c|c|c|c|c|c|c|c|c|}
\hline \multirow{2}{*}{ outlook } & \multicolumn{2}{|c|}{ Moody's } & \multicolumn{6}{c|}{ S\&P } \\
\cline { 2 - 9 } & Coef. & $\mathrm{P}>\mathrm{z}$ & Coef. & $\mathrm{P}>\mathrm{z}$ & Coef. & $\mathrm{P}>\mathrm{z}$ & Coef. & $\mathrm{P}>\mathrm{z}$ \\
\hline dgov & $-0,0337$ & 0,82 & $-0,0223$ & 0,45 & $-0,0010$ & 0,97 & $-0,0771$ & 0,37 \\
\hline dpkb & 0,1459 & 0,60 & 0,0399 & 0,23 & 0,0624 & 0,07 & 0,1986 & 0,06 \\
\hline ddeb & $-0,0509$ & 0,55 & $-0,0918$ & 0,00 & $-0,0982$ & 0,00 & $-0,0579$ & 0,24 \\
\hline dinf & $-0,0795$ & 0,83 & $-0,0003$ & 0,27 & $-0,0003$ & 0,25 & 0,0788 & 0,60 \\
\hline cov & 1,9630 & 0,54 & $-0,6762$ & 0,07 & & & & \\
\hline /cut1 & 1,0545 & & $-2,2093$ & 0,00 & $-2,2383$ & 0,00 & $-0,8495$ & \\
\hline /cut2 & & & 2,7133 & 0,00 & 2,7159 & 0,00 & 4,3497 & \\
\hline obs & 29 & & 875 & & 787 & & 88 & \\
\hline group & & & 90 & & 90 & & & \\
\hline Wald & & & 0,0000 & & 0,0000 & & & \\
\hline LR & 0,9651 & & 0,0000 & \multicolumn{7}{|c|}{0,0000} & & 0,2533 & \\
\hline Rkw & 0,0283 & & & & & & 0,0527 & \\
\hline
\end{tabular}

Legenda: obs - liczba obserwacji, group - liczba krajów, Wald - test Walda, Rkw - skorygowany R kwadrat, LR - test ilorazu wiarygodności, COV - badanie przy uwzględnieniu wpływu wystąpienia COVID-19, NIE COV - badanie dla okresu przed wystąpieniem COVID-19, 2020 - okres występowania COVID-19.

Źródło: opracowanie własne.

\section{Wnioski i podsumowanie}

Celem pracy było zbadanie wpływu kryzysu finansowego wywołanego przez COVID-19 na zmiany nastawienia i zmiany credit ratingów agencji ratingowych. Zaprezentowane wyniki dowiodły istotnego wpływu pandemii COVID-19 na credit rating. Agencją, która najbardziej zmieniła swoje noty w związku z tą sytuacją, jest S\&P. Na badane zjawisko zareagowało nastawienie. Kryzys finansowy wywołany COVID-19 wpłynął negatywnie na zmiany nastawienia krajów. Ponadto dowiedziono występowania kilku interesujących zależności. Ratingi krajów stały się w okresie kryzysu mniej wrażliwe na rosnące zadłużenie, co może być podyktowane powszechnym luzowaniem polityki fiskalnej. Jest to najistotniejsza zmiana we wrażliwości credit ratingów na czynniki na nie wpływające. Dotychczas była to główna zmienna wpływająca na noty krajów. Stopa wzrostu PKB ma szczególny wpływ w okresie COVID-19 w przypadku zmiany outlooku. Jest ona również istotna dla zmian credit ratingów publikowanych przez S\&P. Rosnąca inflacja jest w dobie pandemii szczególnie niebezpieczna. Może mieć to związek z luzowaniem 
polityki pieniężnej. Rosnąca realna stopa wzrostu PKB jest również szczególnie pożądana w okresie kryzysu wywołanego COVID-19.

Prezentowane wyniki wskazują na zmianę metodologii, a tym samym wrażliwości credit ratingów na zmienne odnoszące się do zadłużenia i poziomu rozwoju gospodarczego krajów. Ma to związek z globalną sytuacją rynkową. Agencje ratingowe reagują na COVID-19 z opóźnieniem ze względu na cykliczność oceny. W swoich analizach biorą pod uwagę nie tylko dane ad hoc, ale również dane historyczne i prognozy, tym bardziej że zmianom podlegają głównie ratingi długoterminowe.

\section{Bibliografia}

Ades A., Kaune F., Leme P., Masih R., Tenengauzer D. (2000). Introducing GS-eSS: A New Framework for Assessing Fair Value in Emerging Markets Hard-Currency Debt. „Global Economic Paper", No. 45.

Afonso A. (2003). Understanding the Determinants of Sovereign Debt Ratings: Evidence for the Two Leading Agencies. „Journal of Economics and Finance”, Vol. 27, s. 56-74.

Afonso A., Furceri D., Gomes P. (2012). Sovereign credit ratings and financial markets linkages: Application to European data. „Journal of International Money and Finance”, Vol. 31(3), s. 606-638.

Afonso A., Gomes P., Rother P. (2010). What hides behind sovereign debt ratings? „ECB Working Paper Series", No. 711.

Alesina A., Roubini N. (1992). Political cycles in OECD economies. „Review of Economic Studies", Vol. 59(4), s. 663-688. DOI: 10.2307/2297992.

Allen F., Carletti E., Gale D. (2009). Interbank Market Liquidity and Central Bank Intervention. „Journal of Monetary Economics”, Vol. 56(5), s. 639-652. DOI: 10.1016/j.jmoneco.2009.04.003.

Altman E., Rijken H. (2004). How Rating Agencies Achieve Rating Stability. „Journal of Banking and Finance", Vol. 28(11), s. 2679-2714. DOI: 10.1016/j.jbankfin.2004.06.006.

Altman E., Rijken H. (2009). The Added Value of Rating Outlooks and Rating Reviews to Corporate Bond Ratings. Barcelona: Financial Management Association Meeting.

Amato J., Furfine C. (2004). Are credit ratings procyclical? „Journal of Banking and Finance”, Vol. 28(11), s. 2641-2677. DOI: 10.1016/j.jbankfin.2004.06.005.

Ashbaugh-Skaife H., Collins D., LaFond R. (2006). The Effects of Corporate Governance on Firms Credit Ratings. „Journal of Accounting and Economics”, Vol. 42(1-2), s. 203-243. DOI: $10.1016 /$ j.jacceco.2006.02.003.

Auh J.K. (2013). Procyclical Credit Rating Policy. „Georgetown McDonough School of Business Research Paper”, No. 2581738. DOI: 10.2139/ssrn.2581738.

Bar-Isaac H., Shapiro J. (2013). Ratings quality over the business cycle. „Journal of Financial Economics", Vol. 108(1), s. 62-78. DOI: 10.1016/j.jfineco.2012.11.004.

Bissoondoyal-Bheenick E. (2005). An analysis of the determinants of sovereign ratings. „Global Finance Journal", Vol. 15(3), s. 251-280. DOI: 10.1016/j.gf.2004.03.004.

Bissoondoyal-Bheenick E., Brooks R., Yip A.Y.N. (2006). Determinants of sovereign ratings: A comparison of case-based reasoning and ordered probit approaches. „Global Finance Journal", Vol. 17(1), s. 136-154. DOI: 10.1016/j.gf.2006.06.001. 
Blume M., Lim F., MacKinlay A. (1998). The Declining Credit Quality of U.S. Corporate Debt: Myth or Reality? „Journal of Finance”, Vol. 53(4), s. 1389-1413. DOI: 10.1111/00221082.00057.

Borcuch A. (2009). Globalny system pieniężny. Warszawa: CeDeWu.

Bordo M., Eichengreen B., Klingiebiel D., Martinez-Peira M.S. (2000). Is Crisis Problem Growing More Severe? „Economic Policy: A European Forum”, Vol. 16(32), s. 52-82. DOI: 10.1111/1468-0327.00070.

Borio C., Packer F. (2004). Assessing new perspectives on country risk. „BIS Quarterly Review”, $6^{\text {th }}$ December, s. 47-65. Pobrane z: https://www.bis.org/publ/qtrpdf/r_qt0412e.pdf.

Bozic V., Magazzino C. (2013). Credit Rating Agencies: The Importance of Fundamentals in the Assessment of Sovereign Ratings. „Economic Analysis and Policy”, Vol. 43(2) s. 157-176. DOI: 10.1016/S0313-5926(13)50016-6.

Butler A., Fauver L. (2006). Institutional Environment and Sovereign Credit Ratings. „Financial Management”, Vol. 35(3), s. 53-79, https://doi.org/10.1111/j.1755-053X.2006.tb00147.x.

Caceres C., Guzzo V., Segoviano M. (2010). Sovereign Spreads: Global Risk Aversion, Contagion or Fundamentals? „IMF Working Paper”, No. 10/120. Pobrane z: https://ssrn.com/abstract $=1612590$.

Cantor R., Packer F. (1995). Sovereign Credit Ratings. „FRBNY Current Issues in Economics and Finance", Vol. 1(3), s. 1-6.

Cantor R., Packer F. (1996). Determinants and Impact of Sovereign Credit Ratings. „The Journal of Fixed Income", Vol. 6(3), s. 76-91.

Chee S.W., Fah C.F., Nassir A.M. (2015). Macroeconomics Determinants of Sovereign Credit Ratings. „International Business Research”, Vol. 8(2), s. 42-50.

Chodnicka-Jaworska P. (2015). Credit rating determinants for European countries. „Global Journal of Management and Business Research. Finance", Vol. 15(9), s. 6-18.

Chodnicka-Jaworska P. (2017). Macroeconomic aspects of banks' credit ratings. „Equilibrium. Quarterly Journal of Economics and Economic Policy”, Vol. 12(1), s. 101-120.

Chodnicka-Jaworska P. (2019). Determinanty credit ratingów oraz ich wplyw na rynek finansowy. Warszawa: Polskie Wydawnictwo Ekonomiczne.

Chrabonszczewska W. (2005). Międzynarodowe organizacje finansowe. Warszawa: Szkoła Główna Handlowa. Oficyna wydawnicza.

deHaan E. (2017). The Financial Crisis and Corporate Credit Ratings. „The Accounting Review”, Vol. 92(4), s. 161-189. DOI: 10.2308/accr-51659.

Depken C.A., Lafountain C.L., Butters B.B. (2011). Corruption and Creditworthiness: Evidence from Sovereign Credit Ratings. W: R.W. Kolb (ed.), Sovereign Debt: From Safety to Default. New York: John Wiley \& Sons.

De Santis R.A. (2012). The Euro Area Sovereign Debt Crisis Safe Haven, Credit Rating Agencies and the Spread of the Fever from Greece, Ireland and Portugal. „ECB Working Paper Series", No. 1419.

Feng D., Gourieroux C., Jasiak J. (2008). The Ordered Qualitative Model for Rating Transitions. „Journal of Empirical Finance", Vol. 15, s. 111-130.

Ferri G., Liu L.G., Stiglitz J.E. (1999). The Procyclical Role of Rating Agencies: Evidence from the East Asian Crisis. „Economic Notes”, Vol. 28(3), s. 335-355. DOI: 10.1111/14680300.00016.

Freitag L. (2015). Procyclicality and Path Dependence of Sovereign Credit Ratings: The Example of Europe. „Economic Notes”, Vol. 44(2), s. 309-332. DOI: 10.1111/ecno.12032.

Giacomino P. (2013). Are Sovereign Credit Ratings Pro-Cyclical? A Controversial Issue Revisited in Light of the Current Financial Crisis. „Rivista di Politica Economica”, Issue 4, s. 79-111. 
Guttler A., Raupach P. (2010). The Impact of Downward Rating Momentum. „Journal of Financial Services Research", Vol. 37, s. 1-23.

Guttler A., Wahrenburg M. (2007). The Adjustment of Credit Ratings in Advance of Defaults. „Journal of Banking and Finance”, Vol. 31(3), s. 751-767. DOI: 10.1016/j.jbankfin.2006.05.014.

Haque N.U., Kumar M., Mathieson D., Mark N. (1996). The Economic Content of Indicators of Developing Country Creditworthiness. „IMF Staff Papers”, Vol. 43(4), s. 688-724.

Hill P., Brooks R., Faff R. (2010). Variations in Sovereign Credit Quality Assessments Across Rating Agencies. „Journal of Banking and Finance”, Vol. 34(6), s. 1327-1343. DOI: 10.1016/j. jbankfin.2009.11.028.

Hilscher J., Nosbusch Y. (2010). Determinants of Sovereign Risk: Macroeconomic Fundamentals and the Pricing of Sovereign Debt. „Review of Finance”, Vol. 14(2), s. 235-262.

Hu Y., Kiesel R., Perraudin W. (2002). The Estimation of Transition Matrices for Sovereign Credit Ratings. „Journal of Banking and Finance”, Vol. 26, s. 1383-1406.

Jaramillo L., Tejada C.M. (2011). Sovereign Credit Ratings and Spreads in Emerging Markets: Does Investment Grade Matter? „IMF Working Paper”, No. 11/44, s. 1-18. DOI: $10.5089 / 9781455218981.001$.

Isakin M., David A. (2015). Bayesian Persuasion in Credit Ratings, the Credit Cycle, and the Riskiness of Structured Debt. „Department of Economics, University of Calgary. Working Papers", No. 13.

Kaminsky G. (2003). Varities of Currency Crises. „NBER Working Paper”, No. 10193.

Kim Y., Sohn S. (2008). Random Effects Model for Credit Rating Transitions. „European Journal of Operational Research", Vol. 184(2), s. 561-573. DOI: 10.1016/j.ejor.2006.12.007.

Kräussl R. (2003). Sovereign Ratings and Their Impact on Recent Financial Crises. „CFS Working Paper", No. 2000/04.

Li C., Pervaiz K., Khan M., Rehman F., Oláh J. (2019). On the Asymmetries of Sovereign Credit Rating Announcements and Financial Market Development in the European Region. „Sustainability", Vol. 11(23), s. 1-14. DOI: 10.3390/su11236636.

Löffler G. (2004). An anatomy of rating through the cycle. "Journal of Banking and Finance”, Vol. 28(11), s. 695-720. DOI: 10.1016/S0378-4266(03)00041-4.

Luitel P., Vanpee R. (2018). How do Sovereign Credit Ratings Help to Financially Develop Low-developed Countries? „ECMI Working Paper”, No. 8.

Mennillo G., Sinclair T. (2019). A hard nut to crack: Regulatory failure shows how rating really works. „Competition \& Change”, Vol. 23(3), s. 266-286. DOI: 10.1177/1024529419833870.

Miklaszewski S. (2003). Międzynarodowe stosunki gospodarcze u progu XXI wieku. Warszawa: Difin.

Min H.G. (1998). Determinants of Emerging Market Bond Spread: Do Economic Fundamentals Matter? „World Bank Policy Research Working Paper”, No. 1899.

Minsky H. (1986). Stabilizing an Unstable Economy. London: Yale University Press.

Monfort B., Mulder C. (2000). Using Credit Ratings for Capital Requirements on Lending to Emerging Markets on Lending Economies: Possible Impact of a New Basel Accord. „IMF Working Paper", No. WP/00/69.

Nierenberg B. (2011). Zarządzanie mediami. Ujęcie systemowe. Kraków: Wydawnictwo Uniwersytetu Jagiellońskiego.

Nogués J., Grandes M. (2001). Country Risk: Economic Policy, Contagion Effect or Political Noise? „Journal of Applied Economics”, Vol. 4, s. 125-162.

Oliveira L., Curto J.D., Nunes J.P. (2012). The determinants of sovereign credit spread changes in the Euro-zone. „Journal of International Financial Markets, Institutions and Money”, Vol. 22(2), s. 278-304. DOI: 10.1016/j.intfin.2011.09.007. 
Reisen H., von Maltzan J. (1999). Boom and Bust and Sovereign Ratings. „International Finance", Vol. 2(2), s. 273-293. DOI: 10.1111/1468-2362.00028.

Remolona E., Scatigna M., Wu E. (2008). A Ratings-based Approach to Measuring Sovereign Risk. „International Journal of Finance and Economics”, Vol. 13(1), s. 26-39. DOI: doi.org/10.1002/ijfe.357.

Rowland P., Torres J.L. (2004). Determinants of Spread and Creditworthiness for Emerging Market Sovereign Debt: A Panel Data Study. „Borradores de Economía, Banco de la República”. DOI: 10.32468/be.295.

Teker D., Pala A., Kent O. (2012). Determinants of Sovereign Rating: Factor Based Ordered Probit Models for Panel Data Analysis Modeling Framework. „International Journal of Economics and Financial Issues", Vol. 3(1), s. 122-132.

Trouillet J. (2015). Credit rating agencies, shock and public expectations. Working Papers.

Yalta A., Yalta Y. (2018). Are the Credit Rating Agencies Biased Against MENA Countries? „Economic Research Forum Working Paper”, No. 1274. 